UPPSALA UNIVERSITET

Institutionen för psykologi

Psykologexamensuppsats, 20p

HT 2005

Quality of life, acceptance, and chronic pain -

\title{
A treatment study
}

Magnus Johansson

Handledare

JoAnne Dahl

Examinator

Staffan Sohlberg 


\section{Contents}

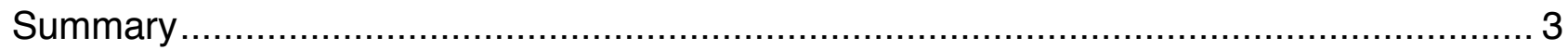

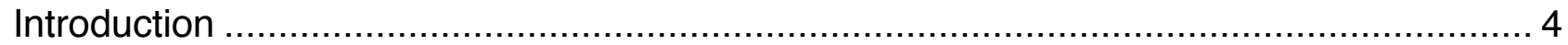

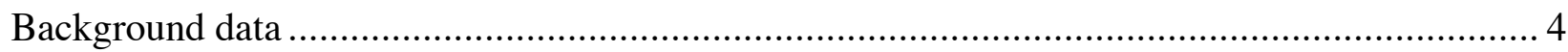

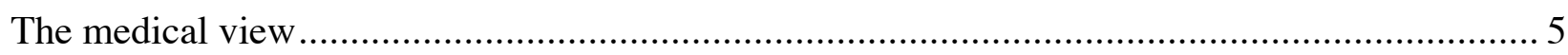

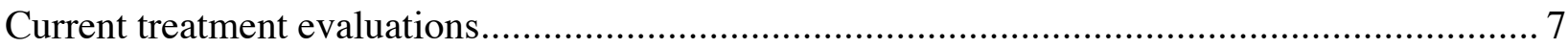

Patient expectations of treatment and problems with attrition ....................................... 8

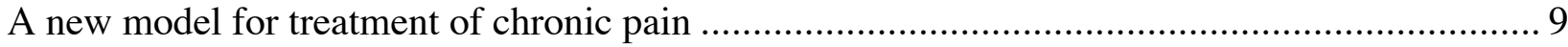

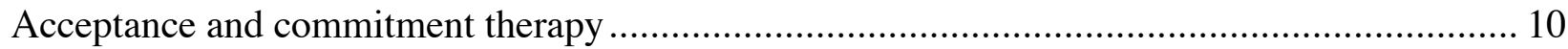

Evaluations of ACT treatment with chronic pain ........................................................ 14

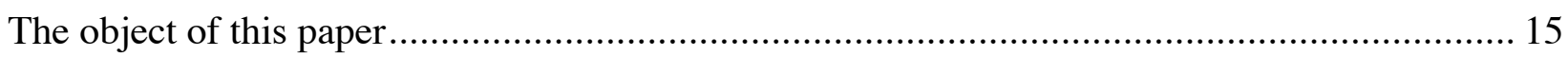

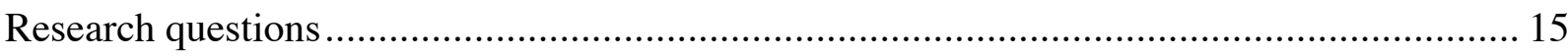

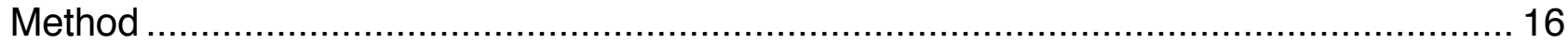

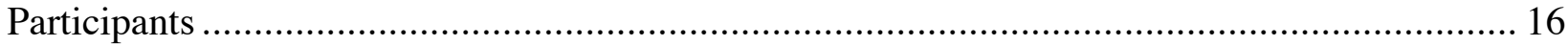

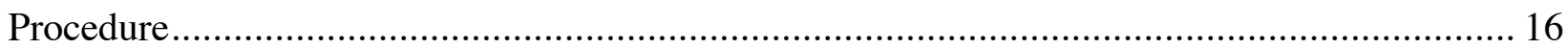

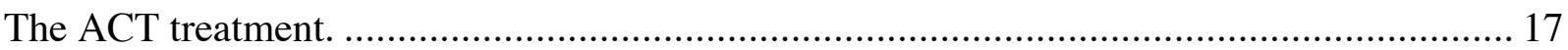

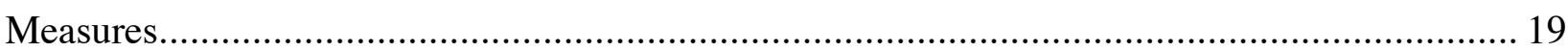

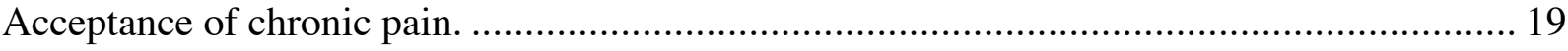

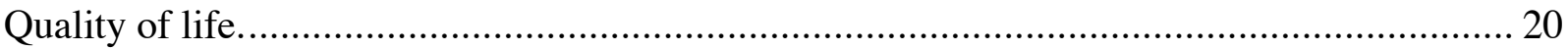

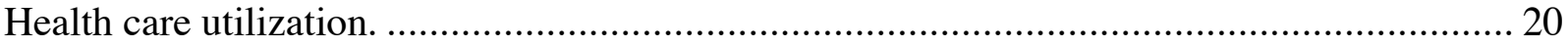

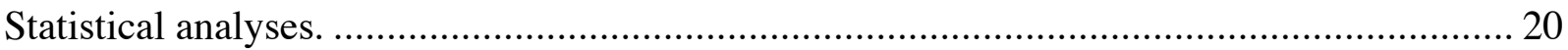

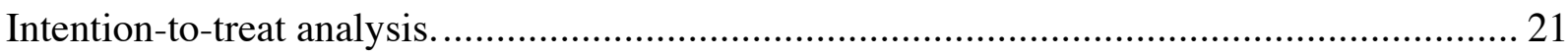

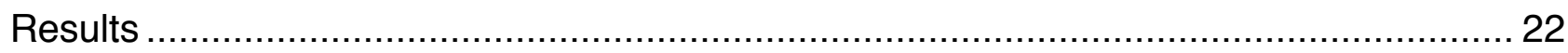

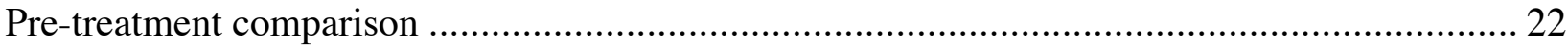

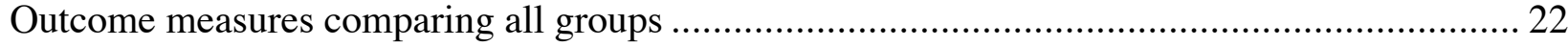

Outcome measures comparing only ACT and TAU groups ........................................... 22

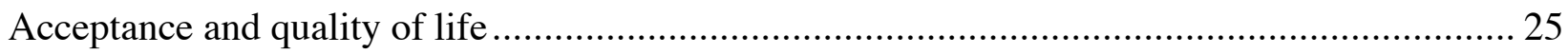

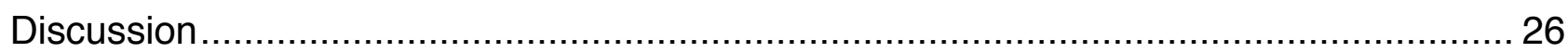

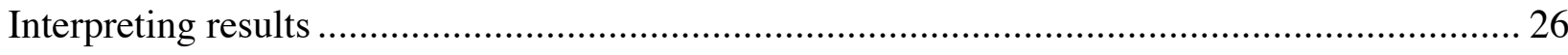

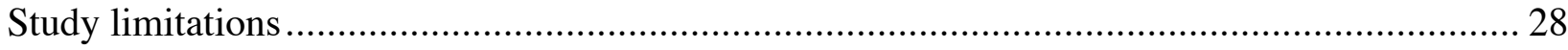

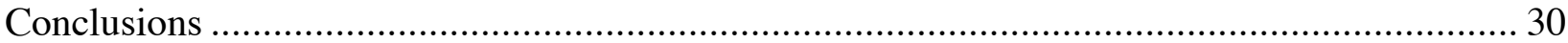

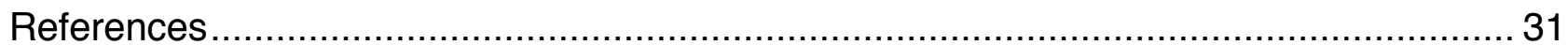




\section{Summary}

Recent data on treatment of chronic pain indicates that acceptance of pain is an important treatment target, highly correlated with outcomes in pain-anxiety, depression and disability. This study is a randomized controlled trial investigating the effects of a brief psychotherapy intervention, based on Acceptance and Commitment Therapy (ACT), compared to a passive and an active control group $(\mathrm{N}=90)$. The treatment begun and ended with an individual session and had two group sessions in between. Outcome data at 3-month follow-up ( $\mathrm{N}=56$ ) showed no significant differences between the groups with regard to acceptance of pain, subjective well-being and health care utilization. Attrition caused impaired statistical power, but effect sizes indicate positive treatment effects. Regression analysis shows that acceptance of pain is able to predict subjective well-being, supporting earlier findings.

Keywords: Acceptance, quality of life, pain, sick-listing, psychological flexibility 
Introduction

Sick-listing is an enormous problem in Sweden. The amount of economic costs and personal suffering is tremendous. The largest part of sick-listed people have some kind of pain-related diagnosis or problem. Treatment for long-term pain is seldom effective, nor is it prioritized by the local government ("landsting") to evaluate existing treatments or finance development of new treatments (Statens beredning för medicinsk utvärdering, 2000). The treatments available are often costly (though they save money in the long run) and timeconsuming. While prevention is very important, the situation is already difficult, with many people suffering. An effective treatment model is needed to help those who are on long term sick-leave to regain quality of life and, if possible, get back to work. Development of effective treatments for chronic pain and related problems should be a high priority.

\section{Background data}

For most of us pain is something that comes and goes, in varying degrees. It is a signal of something being faulty. For some individuals, pain doesn't go away. As pain stays with us over a longer period of time, it often drains much energy and produces anxiety (Ashburn \& Staats, 1999; McCracken \& Gross, 1993). Getting rid of the pain easily becomes a high priority that also consumes much time and money, both for the person suffering as well as the health care system. Work disability is a common consequence of long-term pain, which often leads to sick-listing, which in turn has economic ramifications as well as risks for other difficulties (e.g. depression, see Statens beredning för medicinsk utvärdering, 2003, SBU). Diagnoses with back and neck problems are the largest group (38-41\% in 1999) contributing to sick-leave and early retirement in Sweden (SBU, 2003). In 2002 the cost of sick-leave and early retirement for the Swedish government added up to 98.3 billion SEK (up 10.4\% from 2001). In the year 1995, this number was 30 billion SEK. The total "cost of illness", including loss of production, is calculated at 170 billion SEK for 2002 (ibid.). This is an enormous economic problem. The effect on human suffering is no less significant, but it does not quantify as easily. Unfortunately, suffering is not very likely to be the main argument for decision makers when trying to do something about this predicament. 
Table 1

Sick-days according to the Swedish National Social Insurance

Board, years 1998-2003

\begin{tabular}{cccccc}
\hline 1998 & 1999 & 2000 & 2001 & 2002 & 2003 \\
11,2 & 13,8 & 16,6 & 19,4 & 20,9 & 20,4 \\
\hline
\end{tabular}

Note. Data from Landstingsförbundet, 2005

In 2003, Swedish men had an average of 34.8 sick-days per year, while women had 52 sick-days on average (Landstingsförbundet, 2005). These statistics refer to the sum of all sick benefits available in Sweden ("sjukpenning, arbetsskadesjukpenning, rehabiliteringspenning, sjukersättning och aktivitetsersättning"). The statistics in Table 1 only includes sick-days paid by the Swedish National Social Insurance Board. That means only sick-days that exceeded 14 were used in calculations until 2002, since the employer was responsible for the first 14 days until July 2003. This law was then changed, modifying the number of days that the employer was responsible for from 14 to 21 . The increase of sick-days stops at 2002, with a slight decrease to 2003. In my opinion, the decrease is possibly linked to the changed law regarding the employer's responsibilities, and not because of an actual decrease in total sick-leave numbers. Indications that this is the case can be seen in the same statistical material as referenced above, where the total numbers for cost of sick-leave, rehabilitation and early retirement because of illness continue to increase all the way to year 2003 (Landstingsförbundet, 2005).

\section{The medical view}

Within the medical tradition, chronic pain is viewed as a symptom of an underlying pathology. Medical treatments target the underlying pathology in the service of reducing the symptom. In the absence of damaged tissue of progressive illness, the problem is assumed to be psychological (Vlaeyen \& Morley, 2005). Chronic pain is a disturbing phenomenon for traditional health care, since the medical model doesn't work very well with this group of patients (Dahl, Wilson, Luciano, \& Hayes, 2005). Often damaged tissue coincides with both "normal" pain symptoms as well as neurogenic (nociceptive) symptoms, but there is no perfect correlation between them. Sometimes patients have a 
physical injury but report no pain, while others report pain but have no detectable physical malady (Dahl et al., 2005). The traditional medical model cannot account for this, and is ill equipped to deal with it.

Patients seeking help for chronic pain are met with a wide range of responses from the health care system. Many of the responses reinforce the patient's efforts to get rid of the pain, with no regard to how many other treatments the patient have tried before without getting better. The health care system shapes the concept that pain is "abnormal" and should be avoided at any cost. This encourages further searching for treatment by the patient, despite multiple experiences that most of the treatments offered fail to solve the pain problem (SBU, 2003). Thus, the health care system itself contributes to the spiral of consuming time, money and energy from both the patient and the health care system. The sick-role is sustained. Parson's definition of the sick-role is most relevant in describing and understanding the situation (Roberts, n.d.):

- First, is the exemption from normal social role responsibilities...

- The second closely related aspect is the institutionalised definition that the sick person cannot be expected by "pulling himself together" to get well by an act of decision or will. In this sense also he is exempted from responsibility - he is in a condition that must be "taken care of"...

- The third element is the definition of the state of being ill as itself undesirable with its obligation to want to "get well"...

- ...the fourth..is the obligation...to seek technically competent help...

This emphasizes the medical model's assumption that health is defined by absence of disease (symptoms). As stated in Parson's words "...illness is a state of disturbance in the "normal" functioning of the total human individual, including both the state of the organism as a biological system and of his personal and social adjustments" (Roberts, n.d.). The model is however unable to define "normal functioning" in a useful way when it comes to psychological states. There is little consensus about the concept of normality. Regarding primarily physical diseases, such as injuries and malfunctioning internal organs, assessing normality is not difficult. When discussing normal functioning with regard to psychological well-being, the assessment becomes much more difficult. A diagnostic system has been 
invented and developed since 1952 (Diagnostic and Statistical Manual of Mental Disorders, DSM). The diagnostic criteria have changed during the years, as well as the number of diagnoses, which has increased greatly. The DSM system has been criticized for the high level of co-morbidity (overlapping diagnoses) and it's limited usefulness in planning and carrying out treatments (Hayes, Wilson, Gifford, Follette, \& Strosahl, 1996; Wilson, 1996). This is partly to be expected, since the DSM is intentionally not attached to any specific theory. However, the DSM has been unable to move from describing syndromes to defining diseases, as is the usual procedure within medicine (Hayes et al., 1996). When writing the DSM, the authors used the medical model as a base, with the same basic assumption that health is absence of disease. The DSM has also been used when developing treatments, and symptom reduction is still the primary outcome measure when evaluating psychological and medical treatments. This implies that symptom reduction is also what we strive to achieve in therapy (or any other type of health care) with patients.

Thus the Western medical health system appears to shape the concept of pain as abnormal and pain alleviation as a main focus in the population.

\section{Current treatment evaluations}

In current pain treatments based on cognitive behavior therapy (CBT) and/or behavior therapy (BT) the most common measures for evaluating results are: pain intensity, level of disability, fear of pain/pain anxiety, cognitive coping, physical capacity, use of health care, sick-listing and behavioral activity. Measures are predominantly patient self-ratings. In other words, symptom relief is not the only measure of interest for these treatments. This is most likely a development that is beneficial to the patient, and shows that CBT/BT has moved away from the medical model. The goal is rather to lower disability, increase activity and control unwanted feelings and unhelpful thoughts (Dahl et al., 2005; McCracken, Vowles, \& Eccleston, 2005). Behavioral treatments for chronic pain have been developing since 1976 (Ostelo et al., 2005).

Pain treatment has shown limited success with reducing chronic pain. A meta-analysis has shown that pain decreases with an average of $37 \%$ (compared to $4 \%$ in the control 
groups) after going through a multidisciplinary treatment program (Flor, Fydrich, \& Turk, 1992). The same paper concluded that treated patients were more likely to return to work than the control group (68\% vs. $32 \%)$. Multidisciplinary treatments are quite expensive and time-consuming, and not many chronic pain patients get the chance to participate in such treatments. Morley, Eccleston and Williams (1999) did a systematic review and metaanalysis of CBT/BT for pain. They demonstrated that CBT and BT are equally effective and more effective than control groups in short-term results (no long-term data available). The median effect size (ES, measured here with Cohen's d, where $.20=$ small effect, $.50=$ medium effect, and $.80=$ large effect) found by Morley et al. (1999) was .50. Better treatment outcomes were associated with lower age and shorter duration of pain. The most recent systematic review of CBT/BT treatments (Ostelo et al., 2005) showed a very low short-term ES on pain intensity $(\mathrm{d}=.03)$ and somewhat better, but still low, long-term $E S(d=.24)$. Pooled ES for functional status was $d=.31-.26$ (short term-long term), and for behavioral domain outcome the ES was .19-.32. This tells us that CBT/BT treatments are better than no treatment, while there seems to be room for improvement. In contrast with Morley et al. (1999), Ostelo et al. (2005) found no differences between behavioral treatments and alternative active treatments. According to Vlaeyen \& Morley (2005) the small differences between current treatments makes it hard to avoid the "dodo bird verdict", that there are very small differences between treatment effects.

\section{Patient expectations of treatment and problems with attrition}

At pain clinics, patients are often met with a statement that the pain won't go away, and the treatment program is about living with the pain as well as possible. This often goes against the patients (initial) goal of eliminating the pain (Turk \& Rudy, 1990). Presenting treatment goals without initially discussing this with the patient is bound to be troublesome and cause conflict, even though the clinicians probably are right. Giving a treatment rationale is a precarious situation. If the patient doesn't agree with the rationale, then what? This might contribute to problems with attrition, patients not entering treatment at all, and matching treatment to patient (McCracken \& Turk, 2002; Turk \& Rudy, 1990; Vlaeyen \& Morley, 2005). Attrition is varying in pain treatments. Morley et al. (1999) estimated a $14 \%$ drop-out rate. The studies included in the systematic review by Ostelo et al. (2005) 
had an average drop-out rate of $26.6 \%$ (my calculations), while Flor et al. (1992) found that up to $87 \%$ of participants dropped out during long-term studies. The patients expectation of treatment outcome is an important factor in treatment success (Goossens, Vlaeyen, Hidding, Kole-Snijders, \& Evers, 2005), and will probably be affected by the initial contact with the therapist. Patient expectancy is a much stronger predictor of treatment outcome than how credible the patient thinks that the treatment is. In general, pain patients don't seem to have very high hopes for treatment outcome, probably because they have tried many things before without success (Goossens et al., 2005). This should probably be addressed early in the treatment, or even before entering treatment. Individualized treatments is also likely to increase the patients expectations. According to a study by Hirsh et al. (2005), interpersonal aspects of the health care provider-patient relationship seem to be very important in increasing the likelihood of treatment success and satisfaction.

\section{A new model for treatment of chronic pain}

In recent times acceptance of pain has become more common as a measure and a treatment target. Viane et al. (2003) found that acceptance of pain predicts mental wellbeing. McCracken (1998; McCracken et al., 2005) has discovered similar results regarding the ability of acceptance to predict a range of outcome variables, such as less disability, less depression, less pain-related anxiety and better work status. Acceptance and painrelated anxiety are predictors of disability and these measures can reliably be used to classify patients into subtypes (McCracken, Spertus, Janeck, Sinclair, \& Wetzel, 1999). As stated previously, most of the reported CBT/BT/multidisciplinary treatment programs for chronic pain focus on learning to live with pain. Acceptance is significantly correlated to treatment outcome (McCracken \& Eccleston, 2003, 2005), accounting for more variance in outcome measures than any other variable. Acceptance explains twice as much variance as coping. A lower use of medication and health care is also correlated with acceptance of pain (McCracken, Vowles, \& Eccleston, 2004b). My conclusion of these recent data is that acceptance should be a primary treatment target.

The term acceptance can cause misunderstanding. One could perceive it as a resignation, giving up, which is a passive action. The intended meaning is to actively choose to quit the 
strategies that don't work (usually eliminating pain) and choose to have pain and anxiety when it is in the service of living the life that the person wants to live. This is likely to move the focus from trying to avoid pain in one's life to striving to do the things that one values, even if it involves having pain. Another term is relevant in understanding acceptance, namely willingness. There is a difference in enduring pain when the goal is to habituate and lessen the amount of experienced pain, compared to being willing to have pain when it's in the service of living a valued life. Willingness is also an active choice. Both of these terms are central in the treatment method used in this paper, Acceptance and Commitment Therapy (ACT; Hayes, Strosahl, \& Wilson, 1999).

\section{Acceptance and commitment therapy}

From the ACT perspective, neither suffering nor pain is an anomaly. Suffering is a natural part of life. All living beings suffer at some time(s) during the course of their lives. It is how we relate to and act upon the suffering that defines how problematic it becomes for us. Our ways of handling unwanted feelings is closely connected with how we experience them. According to the ACT model, efforts to control internal, private events (thoughts, feelings, memories, etc.), are often counter-productive. Our control-strategies can become traps of negative reinforcement, avoidance of unwanted feelings (situations) and thoughts in the short-term, leads to more suffering in the long-term. Control is not always counterproductive, it can be useful in some contexts. This is all about the workability of the strategy used. All of us have experience of successful control working, when it is applied in the world outside ourselves, to external events. However, often control is the problem, and it can be difficult to detect, especially when you are the one caught in the middle of it. According to ACT, psychopathology is the result of psychological rigidity (Hayes \& Strosahl, 2004), inability to choose your actions in different situations. The ACT therapist seeks to undermine the processes that make patients maintain inflexible behavior.

A patient seeking therapy usually has the experience of feeling "stuck" in some way in life. When examining the problem using (functional) behavior analysis, it is often apparent that the patient is acting on short-term negative reinforcement. The patient is desperately trying to avoid having certain feelings deemed as unpleasant and unwanted. It is quite possible that this avoidance pattern hasn't been recognized by the patient. Experiential avoidance 
can have significant effects on the patients life, together with cognitive fusion (see p. 13 for explanation) dictating what the patient believes can be done and cannot be done. Fear and avoidance of pain is an important factor in developing a chronic pain problem (Boersma, 2005; Buer \& Linton, 2002; Vlaeyen \& Linton, 2000)

The goal of ACT treatment is to create flexibility that enables the patient to pursue a valued life. Symptom reduction is not a primary goal, even though it is not unlikely that the symptoms will be reduced during or after treatment. There are six components of ACT, described later in the text. These are used as needed by the therapist, which gives flexibility to the therapist as well. Different patients have different needs. The basic "rule" is to do what works. When a patient tells us that she/he has sought treatment to get rid of their pain, we ask, "What would you do if you had no pain? What would happen if you did those things today? Would you be willing to have pain if it means living the life you want to live?" The ACT therapist is helped by assuming that changes can occur quickly during treatment, that the patient is capable of tremendous change in short time. Acceptance of the patient is needed from the therapist, so that the therapist's own internal events do not hinder the treatment. The methods that we use to help the patient create psychological flexibility are the same that we as therapists need to be familiar with, and use in our own lives.

ACT is a behavior therapy. Its foundations are in clinical behavior analysis and Relational Frame Theory (RFT; Hayes, Barnes-Holmes, \& Roche, 2001). ACT is based on a type of pragmatism called functional contextualism. This philosophical connection is apparent through all of ACT. There are three core components of functional contextualism: (1) focus on the whole event, (2) sensitivity to the role of context in understanding the nature and function of an event, and (3) a firm grasp on a pragmatic truth criterion (Hayes et al., 1999, p. 18). At the heart of functional contextualism is its pragmatic truth criterion: successful working, what works is what is "true" (Hayes, 2004). To find out what works, one needs to establish an a priori goal, in order to have something to measure workability against. Thus, truth is always individual and pragmatic. What works for you might not work for me. We may differ in goals and context. Objective, literal truth is not relevant from this perspective, and thus not relevant in treatment either. 
RFT is a theory of human cognition and language. It states that "the core of human language and cognition is the ability to learn to relate events under arbitrary contextual control" (Hayes, 2004, p. 648). A comprehensive presentation of RFT that would increase the understanding of this paper would take considerable space in order to be appropriately complex and concrete. Thus, it is beyond the scope of this paper. For a pedagogic and enjoyable presentation of RFT, see the online tutorial by Eric Fox at "http://www.relationalframetheory.com/tutorial". I will, however, touch upon some practical implications of RFT. There are three critical features of RFT: (1) human cognition is a specific kind of learned behavior; (2) cognition alters the effects of other behavioral processes; (3) cognitive relations and cognitive functions are regulated by different contextual features of a situation (Hayes, Luoma, Bond, Masuda, \& Lillis, 2006). These features have consequences in the area of psychopathology and psychotherapy. This is summarized by Hayes et al. (2006):

(1) Verbal problem solving and reasoning is based on some of the same cognitive processes that can lead to psychopathology, and thus it is not practically viable to eliminate these processes, (2) much as extinction inhibits but does not eliminate learned responding, the common sense idea that cognitive networks can be logically restricted or eliminated is generally not psychologically sound because these networks are the reflection of historical learning processes; (3) direct change attempts focused on key nodes in cognitive networks creates a context that tends to elaborate the network in that area and increase the functional importance of these nodes, and (4) since the content and the impact of cognitive networks are controlled by distinct contextual features, it is possible to reduce the impact of negative cognitions whether or not they continue to occur in a particular form. Taken together, these four implications mean that it is often neither wise nor necessary to focus primarily on the content of cognitive networks in clinical intervention. Fortunately, the theory suggests that it is quite possible instead to focus on their functions. (p. 5)

This is a brief description of the six ACT components (Hayes \& Strosahl, 2004), in no particular order of relevance: 
Acceptance. This has been described earlier in the text. Acceptance is about being nonjudgmental and accept one's thoughts, feelings and bodily sensations for what they are.

Cognitive defusion. ACT does not seek to influence the content of thoughts, nor to inquire whether they are true or not. Patient are often "fused" with their thoughts, having no distance or flexibility towards them. Thoughts are interpreted as literal truths, and can control much of the patients behavior. The goal is to see thoughts as just thoughts. Not valuing or judging them, just taking a step back and seeing them for what they are. And choosing what to do, without regard to the thoughts that show up. If the patient is fused with the thought that "I'll never succeed with anything", then that thought is likely to lead to giving up on things the patient is trying to do, which in turn probably leads to depressed feelings. If the thought is not taken as a literal truth, but as a thought that the mind is giving us, the impact of the thought does not need to be the same. Using the construct of the mind as an object that feeds us a neverending line of thoughts can be useful in objectifying thoughts, taking a new perspective on them. This is an example of a technique that can be used in this area.

Self as context. A sense of self as the context in which thoughts, memories, feelings and sensations occur. This is closely connected to acceptance of one's private events, mindfulness and the next component.

Being in the present moment. To really be present and experiencing things like they are, both internal and external events. Without judging, no matter what thoughts show up. Preconceptions and thoughts about the future are always there to distract us. This usually requires practice. The use of mindfulness techniques and observational exercises help us to be more present. Exposure techniques can be used together with mindfulness, helping the patient to experience feelings like they are and not like the patient's thoughts tell the patient that they are.

Values. This is what guides us in our lives. If we are unclear about values, how can we know what to strive for? How can we have any idea of what action to choose in any given situation? Together with the patient, we look at different aspects of life and try to find out what is important in each area for the patient. What kind of person does one want to be? What kind of relations with other people is valuable? Where does the patient find vitality in life? Trying to find sources of natural positive reinforcement that can guide the treatment 
as a whole, and the patient in life. It is important to remember that these values are not chosen to be "good values", or to be "right". They are chosen by the patient with his/her learning history in mind, trying to disregard influences from society.

Committed action. When goals have been specified, there are steps to be taken in their direction. The patient making commitments to take these steps is important. The patient needs to be responsible for her/his own life, and the commitments are made to oneself, not to the therapist.

For a more thorough description of ACT and the treatment of chronic pain, see the book by Dahl et al. (2005).

\section{Evaluations of ACT treatment with chronic pain}

There are few studies available today on treatments for chronic pain that are primarily ACT-based. Dahl, Wilson \& Nilsson (2004) conducted a short treatment with four individual one-hour therapy sessions, using all components of ACT. The treatment group was compared with a treatment-as-usual (TAU) group. Results, including 6-month follow-up, showed that the ACT-group had fewer sick-days (ES, partial eta squared $=.16$, roughly corresponding to Cohen's $d$ at .90) and used less medical treatment resources (ES, partial eta squared $=.22$, Cohen's d about 1.05) than the TAU-group. No differences between the groups were found regarding stress or pain symptoms. This implies that patient improvements can be made without symptom reduction. More recently, McCracken et al. (2005) published a study utilizing a partly ACT-based group treatment, spanning three or four weeks with treatment five days a week for six hours per day. The treatment was carried out in an interdisciplinary environment. Significant $(p<.01)$ improvements compared to pre-treatment (waiting for treatment) and start of treatment were found both at post-treatment and at the 3-month follow-up measures. Variables most improved include depression ( $d=.55$ at 3-month), hours of rest per day $(\mathrm{d}=.73$ ), physical disability $(\mathrm{d}=.39)$ and psychosocial disability $(\mathrm{d}=.51)$. Number of health care visits diminished $(\mathrm{d}=$ .57 ) and percentage working increased (from $11.4 \%$ to $28.3 \%$ ). Pain symptoms did not decrease significantly. Both studies have methodological shortcomings (i.e. lack of active comparison group) but nevertheless show promising results. 
The object of this paper

Considering the review of existing treatments for chronic pain, and recent findings about the importance of acceptance, it seems appropriate to seek new treatment models that improve upon the existing ones. This study has been influenced by the previous treatment study by Dahl et al. (2004), in its brief treatment period and the ACT content. If a very brief treatment using the ACT model can show results, or at least positive trends, there is cause to pursue further research in using ACT in the treatment of chronic pain. This paper will only review parts of the results of the treatment study. Long-term data (6- and 12-month) has not yet been collected. We hope to present all data in the future, following the proposed follow-ups.

\section{Research questions}

1) How does a short-term treatment using ACT influence subjective quality of life, acceptance of pain and health care utilization in people suffering from chronic pain when compared to groups receiving treatment-as-usual (TAU) or counseling?

2) Can acceptance of pain predict subjective quality of life?

Since previous evaluations of treatments for chronic pain seldom has involved an active control group, a statistical comparison using only the TAU group and the ACT treatment group will also be made, in order to make comparisons with earlier studies possible. 
Method

\section{Participants}

Participants were recruited through ads in two local newspapers, which directed them to either call a number to enlist, or visit a website where more information was available and fill out an application form. The first 115 people to apply for participation in the study received a letter containing the questionnaires being used for the study. 95 of the 115 sent their data back to us, and the first 90 received were randomized (using http://www.random.org) into three groups, each consisting of 30 people. Of the 90 participants, there were 63 women (70\%) and 27 men (30\%), with an age span of 23-65 years ( $M=48,6, S D=10,1)$. The ACT group had 9 full completers (8 with complete data set), 7 missed one of the four treatment sessions, and 2 missed two sessions. All participants came to the first ACT session, 10 reported that they did not want to participate further in the treatment and 2 dropped out without notice. Reasons given for dropping out were mostly not being interested in psychological treatment. The active control group had one counseling session, which all its participants attended.

\section{Procedure}

Group 1 (ACT) received two sessions of individual psychotherapy and two sessions of group psychotherapy. The individual sessions took place before and after the group sessions. Group sizes varied between three and six persons, due to attrition. The treatment was based on Acceptance and Commitment Therapy (Hayes \& Strosahl, 2004; Hayes et al., 1999) and had been previously rehearsed by the four therapists and written down in a treatment manual. The four sessions were completed within five weeks. Group 2 (EC, Experienced Counseling) received one hour of counseling with an experienced occupational therapist, who wanted to evaluate a new questionnaire for pain patients. Group 3 (TAU, Treatment-As-Usual) got no additional treatment, they were asked to continue with their current and/or planned treatments. It is not entirely correct to name the "no-treatment" group as TAU, since they were not participating in any collective "treatmentas-usual" that we know of. It would perhaps be more correct to see the TAU group as a passive control group. Qualitative data is available on the treatments that all participants were involved in during the treatment and at post-treatment measures. These data have not been processed in the current study. 
Participants filled out the questionnaires prior to starting the ACT/EC treatment, and directly after finishing the ACT treatment. Those in the ACT group received their questionnaires after their last session, whereas we mailed questionnaires to the other participants at the same time. Questionnaires were sent out by mail again after three months.

There were four therapists conducting the ACT treatment, working in pairs during the group sessions. All therapists had previous training in ACT. Two of the therapists were students on the last semester of the psychologist program at Uppsala University, one therapist was a PTP-psychologist (clinical practice rotation), and one was a step-1 trained CBT-therapist. Each duo of therapists consisted of one student and one more experienced therapist. Supervision was provided by a licensed psychotherapist and PhD with considerable experience from utilizing ACT and working with chronic pain patients.

\section{The ACT treatment.}

For a more complete description of the ACT treatment, see appendix A, containing the working manual that was used by the therapists. In part since the working manual is written in Swedish, I have made a short description of the core of each session in the following paragraphs. It should be noted that the manual was used as a guideline, from which the therapists could make deviations if required by the current situation. The parts that I have summarized below took place in all sessions, and can be considered the most important parts of the treatment.

Session 1 (individual, 45-90 minutes). The therapist presents the treatment outlines for the client. This session is focused on discussing the workability of previous treatments and strategies that the client has tried in order to get rid of the pain, doing work with values in life, and connecting these components to each other. Together with the client, the therapist examines if previous strategies have helped the client to get closer to living a valued life. The client receives a homework assignment: filling out the "life compass", a chart with ten life domains in which the client fills out values/goals, obstacles they encounter trying to reach their goals, and level of importance in each domain. 
Session 2 (group, about three hours). Following the presentation of the therapists (two therapists and 3-7 clients), the session starts with a mindfulness exercise, based on the "Observer exercise" (p. 192-195, Hayes et al., 1999). We drew a circle on the whiteboard around the word "pain". The clients were asked to mention words associated with pain, and we discussed "clean vs dirty" pain (p. 136, ibid.). Other experiential exercises used were the "bus metaphor" (adapted from p. 157-158, ibid.) and, if time was available, the "funeral exercise" (adapted from p.215-218, ibid.). The bus metaphor was linked with the mindfulness exercise that started the session ("can you observe the passengers without acting upon them? Like you did with your thoughts and feelings in the exercise earlier?", etc.). At the end of the session everyone received a new homework assignment: the "bullseye diary" and the "tombstone" (see appendix B). Before ending the session all participants filled out the first page of the bulls-eye instrument, making a commitment in front of the group about a concrete activity that they would do until the next meeting, to get closer to their values in the chosen life domain.

Session 3 (group, about three hours). We started this session with approximately the same mindfulness exercise as in session 2 , this time combining the "observing self" with an adaption of "soldiers in the parade exercise" (p. 158-161, Hayes et al., 1999). The "chessboard metaphor" (p. 190-192, ibid.) was presented, role-played and discussed. We did another role-playing exercise, using the scene of a "rehabilitation meeting", something that most clients with chronic pain problem have gone through. One of the therapists played the part of a client, and the clients played the other people attending the meeting (physician, representative from work and "försäkringskassan", etc.). Two versions of the role-play were made, with the therapist acting as client radically changing his behavior between the two role-plays. The "kick your but's exercise" (p. 167, ibid.), was carried out, and a discussion of the implications of that exercise, combined with talking about control. The homework assignment after session 3 was a self-report form for mindfulness exercises carried out during the time until session 4.

Session 4 (individual, 45-90 minutes). The focus of the final session was to summarize and conclude the treatment in collaboration with the client. Discussing what the client thinks has been useful or not during the earlier sessions, as well as trying to see what the client has the most problems with and work with those areas. Thus it is a most flexible 
session. At the end of the session we talked more about what to do next, how to go on from here, how to live a valued life.

\section{Measures}

Six instruments were used during the study: Chronic Pain Acceptance Questionnaire (CPAQ), Tampa Scale of Kinesiophobia (TSK), Pain Disability Index (PDI), SF-36 Swedish Acute Version, Satisfaction With Life Scale (SWLS), Outcome Evaluation Questionnaire (OEQ). However, not all of them are subject for this paper. CPAQ, SWLS, and one item from $O E Q$, will be used. The dependent variables represented by these instruments are subjective quality of life, acceptance of chronic pain, and health care utilization.

\section{Acceptance of chronic pain.}

The Chronic Pain Acceptance Quesionnaire (CPAQ) is a 20-item self-report questionnaire, developed by Geiser (Geiser, 1992). It is originally derived from the Acceptance and Action Questionnaire (Hayes et al., 2004b) and has been designed to measure acceptance of chronic pain. The scoring is performed on a seven-point scale, ranging from never true to always true. According to McCracken (McCracken, Carson, Eccleston, \& Keefe, 2004a; McCracken \& Eccleston, 2005; McCracken et al., 1999; McCracken et al., 2004b), the CPAQ has been shown to have two components, (a) Activities Engagement (11 items) and (b) Pain Willingness (9 items). The internal consistency of subscales and total scores is good ( $\alpha=.78-.82$; (McCracken et al., 2004b). The CPAQ demonstrates significant correlations with measures of avoidance, emotional distress and patient functioning in cross-sectional analyses, which supports its validity as indices of acceptance of chronic pain (McCracken, 1998; McCracken \& Eccleston, 2003; McCracken et al., 2004b). A swedish translation of the CPAQ was used in this study. The translation was made by Kristoffer Lundmark/Bothelius, Ned Carter, Lennart Melin and Rikard Wicksell. Item examples are: "When my pain increases, I can still take care of my responsibilities" and "I avoid putting myself in situations where my pain might increase". Swedish data for the CPAQ is currently unavailable. See appendix $C$ for the Swedish translation of CPAQ. 


\section{Quality of life.}

The Satisfaction With Life Scale (SWLS) seeks to measure global, rather than specific, life satisfaction and subjective well-being (Diener, Emmons, Larsen, \& Griffin, 1985). The questionnaire contains five statements, to which the participant is asked to indicate level of agreement on a seven-point scale ranging from 1 (strongly disagree), to 7 (strongly agree). Item examples (in Swedish) are: "I am satisfied with my life" and "If I could live my life over, I would change almost nothing". The SWLS has been shown not to be evoking social desirability responses. It's coefficient alpha is at .83-.87, and two-month test-retest correlation coefficient is at .82, while 2-week retest was at .84 and one month retest at .85 (Diener et al., 1985; Pavot, Diener, Colvin, \& Sandvik, 1991). Validation made by Diener et al. (1985) and Pavot et al. (1991) shows that the SWLS is "a valid and reliable measure of life satisfaction, suited for use with a wide range of age groups and applications, which makes possible the savings of interview time and resources compared to many measures of life satisfaction." (Pavot et al., 1991). See appendix C for the swedish translation of SWLS.

Health care utilization.

This variable was measured using one item from the Outcome Evaluation Questionnaire (Linton, Keefe, Jansson, \& Aslaksen, 1992): "How many times during the last month have you sought health care because of your pain?".

\section{Statistical analyses.}

If less than $10 \%$ of a patient's items on a measure was missing, the item data was filled in using the patient's mean score on the measure (Bryman \& Cramer, 2000). Last observation carried forward was used from post-treatment measures to 3-month measures, resulting in 2 more participants with "complete" data in each group. SPSS General Linear Model Repeated Measures with data from pre-measures, post-measures and 3-month follow-up measures was used for analyses of the SWLS and the CPAQ. Variations in number of participants between different tests are due to missing data. See 
Table 2 for data on number of participants. Since the HCU measure showed significance on the Kolmogorov-Smirnov test, and data transformation did not make parametric testing appropriate, the Kruskal-Wallis test was used when comparing all groups, and the MannWhitney test was used when comparing only ACT and TAU groups. A stepwise regression analysis was computed between the post-treatment measure of the CPAQ and the 3month follow-up data on the SWLS.

Intention-to-treat analysis.

Participants in the ACT condition with two or more treatment sessions completed were defined as completers. The ACT $n$ decreased with 2 regarding SWLS measures, 3 regarding $C P A Q$, and 2 regarding health care utilization when removing non-completers from the analyses. Small differences in group sizes at 3-month follow-up data makes for small differences in outcome data as well. Since no significant differences were found in analyses using only completers versus using all data, only analyses using all data will be reported. 


\section{Results}

Pre-treatment comparison

Pre-treatment differences between groups in dependent measures were non-significant. When comparing the pre-treament CPAQ score of ACT group completers $(n=16, M=$ 66.6, $S D=12.9)$ to non-completers $(n=10, M=79.7, S D=12.3)$ there was a significant difference $\left(p=.017\right.$, partial eta squared $\left.\left(\eta^{2}\right)=.215\right)$, showing that non-completers scored higher on the CPAQ (more accepting). No significant differences comparing completers/non-completers with the other groups were found.

\section{Outcome measures comparing all groups}

No significant main or interaction effects were found in any of the measures. Medium effect sizes were found in the SWLS measure and the CPAQ Pain Willingness factor. See Table 2 for a summary of outcome measures cell data, Table 3 for ANOVA data, Table 4 for the HCU measure data, and Figures D1-D5 in Appendix D for visual data.

\section{Outcome measures comparing only ACT and TAU groups}

The CPAQ total score showed a significant interaction effect between treatment group and time $\left(p=.033\right.$, partial $\left.\eta^{2}=.108\right)$. An analysis of the subfactors of the CPAQ showed a significant interaction effect (Treatment group $X$ Time) for the Activities Engagement factor $\left(p=.050\right.$, partial $\left.\eta^{2}=.095\right)$ but not the Pain Willingness factor $\left(p=.128\right.$, partial $\left.\eta^{2}=.066\right)$.

Subjective well-being (SWLS) and health care utilization did not show any significant effects or interactions. See Table 5 for the HCU measure data and Table 6 for ANOVA data. 
Table 2

Scores on outcome measures

\begin{tabular}{|c|c|c|c|c|c|c|c|c|c|}
\hline \multicolumn{10}{|c|}{ Measure and time of } \\
\hline & $n$ & $M$ & $S D$ & $n$ & $M$ & $S D$ & $n$ & $M$ & $S D$ \\
\hline \multicolumn{10}{|l|}{ SWLS } \\
\hline Pre & & 21.6 & 7.0 & & 18.9 & 7.2 & & 21.2 & 8.3 \\
\hline Post & & 24.3 & 7.8 & & 19.1 & 6.8 & & 21.9 & 7.6 \\
\hline 3-month & 16 & 21.9 & 7.6 & 22 & 17.5 & 7.7 & 19 & 21.3 & 7.8 \\
\hline \multicolumn{10}{|l|}{ CPAQ Total } \\
\hline Pre & & 68.9 & 16.8 & & 64.1 & 12.6 & & 73.2 & 17.1 \\
\hline Post & & 79.7 & 19.5 & & 70.1 & 16.9 & & 74.1 & 15.0 \\
\hline 3-month & 14 & 78.0 & 20.0 & 21 & 69.1 & 15.8 & 18 & 75.6 & 16.0 \\
\hline \multicolumn{10}{|c|}{ CPAQ Activities Engagement } \\
\hline Pre & & 35.4 & 10.9 & & 31.9 & 7.8 & & 37.0 & 10.2 \\
\hline Post & & 39.8 & 13.8 & & 35.3 & 11.5 & & 35.6 & 8.5 \\
\hline 3-month & 14 & 39.6 & 13.1 & 21 & 34.1 & 11.2 & 18 & 35.9 & 9.6 \\
\hline \multicolumn{10}{|c|}{ CPAQ Pain Willingness } \\
\hline Pre & & 33.5 & 7.6 & & 31.9 & 9.1 & & 36.1 & 9.1 \\
\hline Post & & 39.9 & 8.2 & & 35.5 & 9.2 & & 38.5 & 9.2 \\
\hline 3-month & 14 & 38.4 & 8.7 & 21 & 35.1 & 8.4 & 18 & 40.1 & 9.2 \\
\hline \multicolumn{10}{|l|}{$\mathrm{HCU}$} \\
\hline Pre & & 1.8 & 1.9 & & 2.1 & 3.6 & & 2.5 & 3.8 \\
\hline Post & & 1.0 & 1.4 & & 1.9 & 3.2 & & 2.0 & 2.9 \\
\hline 3-month & 14 & 0.7 & 0.9 & 22 & 0.8 & 1.2 & 19 & 1.1 & 2.8 \\
\hline
\end{tabular}


Table 3

Outcome measures

comparing all groups

\begin{tabular}{lcccc}
\hline Outcome measure & $F$ & $d f$ & $p$ & $\begin{array}{c}\text { partial eta } \\
\text { squared }\end{array}$ \\
\hline SWLS & & & & \\
$\quad$ Main effect & 1.703 & 2,54 & .192 & .059 \\
$\quad$ Time X Group interaction & 1.318 & 4,108 & .268 & .047 \\
CPAQ Total & & & & \\
$\quad$ Main effect & 1.297 & 2,50 & .282 & .049 \\
$\quad$ Time X Group interaction & 1.750 & 4,100 & .145 & .065 \\
CPAQ Activities Engagement & & & & \\
$\quad$ Main effect & 0.954 & 2,50 & .392 & .037 \\
$\quad$ Time X Group interaction & 1.602 & 4,100 & .180 & .060 \\
CPAQ Pain Willingness & & & & .054 \\
$\quad$ Main effect & 1.423 & 2,50 & .251 & .048 \\
$\quad$ Time X Group interaction & 1.249 & 4,100 & .295 &
\end{tabular}

Note. Main effect refers to the Treatment group variable.

Table 4

HCU measure comparing all groups using Kruskal-Wallis test

\begin{tabular}{lcccc}
\hline $\begin{array}{c}\text { Time of } \\
\text { measurement }\end{array}$ & $N$ & Chi-squared & $d f$ & $p$ \\
\hline $\begin{array}{l}\text { Pre-treatment } \\
\text { Post-treatment }\end{array}$ & 89 & 1.635 & 2 & .442 \\
$\begin{array}{l}\text { 3-month follow- } \\
\text { up }\end{array}$ & 57 & 0.049 & 2 & .976 \\
\hline
\end{tabular}

Table 5

HCU measure comparing ACT and TAU groups using Mann-Whitney test

\begin{tabular}{lccc}
\hline $\begin{array}{c}\text { Time of } \\
\text { measurement }\end{array}$ & $N$ & $U$ & $p$ \\
\hline $\begin{array}{l}\text { Pre-treatment } \\
\text { Post-treatment }\end{array}$ & 59 & 359.0 & .228 \\
$\begin{array}{l}\text { 3-month follow- } \\
\text { up }\end{array}$ & 35 & 150.5 & .957 \\
\hline
\end{tabular}


Table 6

Outcome measures

comparing ACT and TAU groups

\begin{tabular}{|c|c|c|c|c|}
\hline Outcome measure & $F$ & $d f$ & $p$ & $\begin{array}{c}\text { partial eta } \\
\text { squared }\end{array}$ \\
\hline \multicolumn{5}{|l|}{ SWLS } \\
\hline Main effect & 0.202 & 1,33 & .656 & .006 \\
\hline Time X Group interaction & 1.395 & 2,66 & .255 & .041 \\
\hline \multicolumn{5}{|l|}{ CPAQ Total } \\
\hline Main effect & 0.048 & 1,30 & .828 & .002 \\
\hline Time X Group interaction & 3.623 & 2,60 & $.033 *$ & .108 \\
\hline \multicolumn{5}{|l|}{ CPAQ Activities Engagement } \\
\hline Main effect & 0.452 & 1,30 & .507 & .015 \\
\hline Time X Group interaction & 3.159 & 2,60 & $.050^{*}$ & .095 \\
\hline \multicolumn{5}{|l|}{ CPAQ Pain Willingness } \\
\hline Main effect & 0.156 & 1,30 & .695 & .005 \\
\hline Time X Group interaction & 2.131 & 2,60 & .128 & .066 \\
\hline
\end{tabular}

Note. Main effect refers to the Treatment group variable. ${ }^{*} \mathrm{p} \leq .05$

\section{Acceptance and quality of life}

A stepwise regression analysis using pre-treatment data of age and duration of pain, and post-treatment data of health care utilization and CPAQ subfactor scores to predict SWLS 3-month follow-up data was computed. This showed that only the CPAQ Activities Engagement (CPAQ-AE) factor predicts SWLS total score $\left(p<.001\right.$, adjusted $\left.r^{2}=.260\right)$.

Table 5

Stepwise linear regression of SWLS score at 3-month follow-up data

\begin{tabular}{lcccccc}
\hline $\begin{array}{c}\text { Dependent } \\
\text { variable }\end{array}$ & $N$ & $\begin{array}{c}\text { Adjusted R } \\
\text { squared }\end{array}$ & Predictor & Beta & $p$ & $B$ \\
\hline $\begin{array}{l}\text { SWLS, 3- } \\
\text { month }\end{array}$ & 56 & .260 & $\begin{array}{c}\text { CPAQ-AE, } \\
\text { post }\end{array}$ & .523 & $<.001$ & .371 \\
\hline
\end{tabular}

Note. The other measures that were entered into the stepwise regression were: age, duration of pain (both pre-measures), CPAQ Pain Willingness and HCU (both post-treatment measures). These measures did not contribute significantly. 


\section{Discussion}

The results of this study at a relatively short follow-up showed a mixed quality of support for the hypotheses proposed.

The main question underlying this study was to evaluate if a short-term ACT treatment produced different outcomes than the active and passive control groups. The results from this study at the 3-month follow-up did not show significant differences between the ACT intervention and other conditions. There are indications of group differences and results may over time show to be different.

A second objective was to investigate whether acceptance of pain could predict subjective well-being. The results of this study did provide supporting evidence for this hypothesis, showing that the Activities Engagement factor of the CPAQ had good predictive properties.

\section{Interpreting results}

Looking at the results regarding research question 1 it seems that the differences are small, or even non-existing. Not finding any significant main effects implies accepting the null hypothesis. However, the statistical power analysis that was done when planning this study showed that 30 participants per group would be necessary an adequate level of power (.85). The high level of attrition has reduced the statistical power in the analyses. While the outcome measures differ, the effect sizes on the CPAQ and SWLS are about the same or better than effect sizes found in meta-analyses of CBT/BT treatments versus no treatment (Ostelo et al., 2005). They are also comparable to some of the results in the interdisciplinary, in part ACT-based treatment conducted by McCracken et al. (2005), though they did not have an active comparison group. The study by Dahl, et al. (2004) had much stronger effect sizes regarding usage of medical treatment resources, but those results were not apparent until at 6-month follow-up (no active comparison group). Although the present study shows improvements in health care utilization in all groups, it is possible that group differences will be discernible when more follow-up data is available. The Dahl et al. (2004) study used only individual therapy sessions. While there is no clear evidence on individual versus group treatment of pain patients using a psychological treatment model, this may be a decisive difference. The study by McCracken et al. (2005) 
showed effect sizes in CPAQ scores comparable to the current study. The number of participants was much larger, and treatment was substantially more extensive in time than in this study, and there were no comparison groups.

In moving from a symptom focused perspective, this study used subjective quality of life as a primary outcome measure. If quality of life is to be used as a possibly intrinsically important measure, this evokes the question about how to use it as a treatment target. Perhaps other variables mediate quality of life? While not a mediating analysis, the regression analysis computed in this supports earlier findings concerning the relationship between acceptance and well-being. The predictive factor of the CPAQ, Activities Engagement, is defined as "engaging in normal life activities regardless of pain". In order to develop efficient treatments, there is a need to know which variables that are important to focus on in treatment. Activities engagement is likely to be an adequate objective.

Activities engagement sounds much like what most CBT/BT treatments for chronic pain also emphasize: the need to do things in the face of pain. This is also similar to efficient treatment of depression, behavioral activation, where the patients seem to have lost contact with large parts of their valued life, and needs to do things in the face of feeling depressed. Almost every behaviorally based therapy has exposure of the feared situation or emotion as a primary treatment method (OCD, PTSD, phobia, etc.). There seems to be an inference that exposure is the key, or at least a very important treatment component. This also supports the concept of experiential avoidance as an important factor in explaining patient suffering.

The ACT model theorizes that the context of exposure training is important, and that acceptance of pain is crucial. The next question is whether context really makes a difference. We should expect greater and perhaps more generalized effects from valuesrelated exposure than traditional exposure if the ACT model is correct. Clarifying values is likely to have motivational side-effects, as well as more generalized effects since the persons whole life is brought to attention. If the patient experiences that the experiential avoidance model of suffering works, self-exposure in other areas of life might appear spontaneously. This remains to be proven. The other components of ACT also need to be investigated further. 


\section{Study limitations}

What are the possible explanations for the results of this study? One hypothesis could be that the treatment model might be inadequate. There is limited evidence for the efficacy of ACT for other patient groups, and very limited data for chronic pain treatment. However, the available evidence has shown results similar to, or better than current treatments (Hayes, Masuda, Bissett, Luoma, \& Guerrero, 2004a). More data is needed to strengthen the support for the ACT model.

When considering previous studies on acceptance of pain and its correlations with other measures, there seems to be adequate data in favor for acceptance as an important factor in chronic pain. The regression analysis in this study supports these findings. Acceptance should be prioritized in any treatment of chronic pain, and the ACT model seems well suited for this. It is possible that the factor of acceptance should have been emphasized more in the present study.

One threat to the validity of the study is that the therapists had no previous experience working with this group of patients, and limited clinical experience overall. Since the initial stage of the ACT therapy largely consists of moving the patient's focus from removing the pain to living a valued life with the pain, there is a risk for conflict. The initial patient contact needs to be tactful and at the same time focused on function rather than content of what the patient is saying. It is likely to require more training than role-play to achieve an adequate level of competence.

Treatment adherence and therapist competence were not assessed. This would have required patients willing to be recorded on video or audio tape, and a considerable amount of time and work coding sessions. This was not possible within the time-span and economical limits of this study. One consequence of the high drop-out rate was that in some instances the group sessions had as few as three participants. This affected the planned interventions, of which some could not be carried out.

The drop-out rate is an important subject in all treatments. It is seldom the case that one treatment model fits all patients. There were no efforts made in this study to match patient to treatment. In the advertisement for participants there was no information about what kind of treatment that was about to be evaluated. Many of the participants in the ACT 
group were initially doubtful of the idea of "getting psychological treatment for something that was obviously somatic". This is a common notion in our society, and needs to be addressed in an adequate way when presenting the treatment. All 30 participants did show up at the first session, which implies interest in the treatment, maybe hope for a cure, or perhaps just social compliance? The first session could conceivably have profited from being designed in a more motivational manner, in order to get more patients to stay in treatment. The transition from the medical "quick fix/passive patient-role" mental state to a more long-term psychological acceptance requires substantial skills in motivational methods. One of the ingredients in the ACT treatment, often used in the initial stage, is called "creative hopelessness". It is built on the patients experiences that previous attempts at solving the pain problem have not worked. This experience that short-term solutions have not worked serves as motivation for trying a different approach. It is not unlikely that the patient needs to have experienced several unsuccessful attempts to reduce pain in order to use the "creative hopelessness" component.

Inexperienced therapists might also be problematic regarding difficulties with patients claiming to have no interest in the treatment. The patients constituted a heterogeneous sample, since type of pain or duration was not taken into consideration when excluding and randomizing participants. The only exclusion criteria was an upper age limit at 65 years. This could be argued to give a good ecological validity, but on the other hand, many suffering from chronic pain are over 65 years old.

Looking at the figures and trend data, there is an increase in SWLS and CPAQ scores in the ACT condition between pre-treatment and post-treatment measures. This is followed by a slightly declining trend. Extra attention awarded to those who participated in the active groups could be the sole reason for the effects that have been measured. This trend is especially distinct regarding the ACT-group's SWLS score, where the 3-month data show a complete rebound to pre-treatment scores. The CPAQ and HCU have more stable effects at 3-month follow-up.

The treatment used in this study is relatively brief, which could make it more sensitive to attrition effects. It also puts greater pressure on the therapists to perform efficiently. The combination of individual and group sessions is cost-effective, if it works. At least two of the four therapists involved had a feeling that one individual session before the group 
sessions was not enough. The group was very heterogeneous when coming in to the first group session. It is also likely that if all sessions had been individual the treatment effect might have been larger. Flexibility is important in the ACT model, and it is also important that the therapist is flexible. Even if the working manual wasn't used rigorously as a stepby-step treatment manual, it still imposed some restrictions on the therapist. For example, there were mandatory home assignments that required certain things to be covered in session. A more flexible therapist also need to be more skilled at recognizing the specific needs of the client, especially in a very short treatment. Perhaps there is a need for a middle-ground here, a treatment manual can be used more flexibly. But it is difficult to evaluate such loosely defined therapy. It would demand a thorough description of each session, which would render large amounts of data that might be hard to quantify.

\section{Conclusions}

The conclusion of this study is that this short-term ACT therapy did not differ from the treatments at large at the short-term follow-up. Acceptance needs to be investigated further as a treatment target, whether using the ACT model or not. Values-guided exposure versus non-values-guided exposure, as well as the role of acceptance in exposure, are interesting and highly relevant research questions for ACT and behavior therapy in chronic pain and other settings. Future research should contain these components, and could for example be done in the form of an ACT treatment using 4-6 individual sessions, perhaps in conjunction with "booster sessions", to see if it would make for more durable treatment effects. Personally, I want to emphasize that the view on symptom reduction as a treatment goal needs to be taken into serious consideration; the person administering treatment, be it psychological or somatic medical care, should be aware of the possible consequences of different views. 


\section{References}

Ashburn, M. A., \& Staats, P. S. (1999). Management of chronic pain. Lancet, 353(9167), 1865-1869.

Boersma, K. (2005). Fear and avoidance in the development of a persistent musculoskeletal pain problem.: Implications for secondary prevention. Örebro: Örebro universitetsbibliotek.

Bryman, A., \& Cramer, D. (2000). Quantitative data analysis with spss release 10 for windows: A guide for social scientists. London: Routledge.

Buer, N., \& Linton, S. J. (2002). Fear-avoidance beliefs and catastrophizing: Occurrence and risk factor in back pain and adl in the general population. Pain, 99(3), 485-491.

Dahl, J., Wilson, K. G., Luciano, C., \& Hayes, S. C. (2005). Acceptance and commitment therapy for chronic pain. Reno: Context Press.

Dahl, J., Wilson, K. G., \& Nilsson, A. (2004). Acceptance and commitment therapy and the treatment of persons at risk for long-term disability resulting from stress and pain symptoms: A preliminary randomized controlled trial. Behavior Therapy, 35(4), 785801.

Diener, E., Emmons, R. A., Larsen, R. J., \& Griffin, S. (1985). The satisfaction with life scale. Journal of Personality Assessment, 49(1), 71-75.

Flor, H., Fydrich, T., \& Turk, D. C. (1992). Efficacy of multidisciplinary pain treatment centers: A meta-analytic review. Pain, 49(2), 221-230.

Geiser, D. S. (1992). A comparison of acceptance-focused and control-focused psychological treatments in a chronic pain treatment center. unpublished PhD diss.

Goossens, M. E., Vlaeyen, J. W., Hidding, A., Kole-Snijders, A., \& Evers, S. M. (2005). Treatment expectancy affects the outcome of cognitive-behavioral interventions in chronic pain. The Clinical Journal of Pain, 21(1), 18-26.

Hayes, S. C. (2004). Acceptance and commitment therapy, relational frame theory, and the third wave of behavioral and cognitive therapies. Behavior Therapy, 35(4), 639665.

Hayes, S. C., Barnes-Holmes, D., \& Roche, B. (2001). Relational frame theory: A postskinnerian account of human language and cognition. New York; London: Kluwer Academic/Plenum Publishers. 
Hayes, S. C., Luoma, J. B., Bond, F. W., Masuda, A., \& Lillis, J. (2006). Acceptance and commitment therapy: Model, processes and outcomes. Behaviour Research and Therapy, 44(1), 1.

Hayes, S. C., Masuda, A., Bissett, R., Luoma, J., \& Guerrero, L. F. (2004a). DBT, FAP, and ACT: How empirically oriented are the new behavior therapy technologies? Behavior Therapy, 35(1), 35-54.

Hayes, S. C., \& Strosahl, K. (2004). A practical guide to acceptance and commitment therapy. New York: Kluwer Academic/Plenum Publishers.

Hayes, S. C., Strosahl, K., Wilson, K. G., Bissett, R. T., Pistorello, J., Toarmino, D., et al. (2004b). Measuring experiential avoidance: A preliminary test of a working model. The Psychological Record, 54, 553-576.

Hayes, S. C., Strosahl, K. D., \& Wilson, K. G. (1999). Acceptance and commitment therapy: An experiential approach to behavior change. New York; London: Guilford Press.

Hayes, S. C., Wilson, K. G., Gifford, E. V., Follette, V. M., \& Strosahl, K. (1996).

Experiential avoidance and behavioral disorders: A functional dimensional approach to diagnosis and treatment. Journal of Consulting and Clinical Psychology, 64(6), 1152-1168.

Hirsh, A. T., Atchison, J. W., Berger, J. J., Waxenberg, L. B., Lafayette-Lucey, A., Bulcourf, B. B., et al. (2005). Patient satisfaction with treatment for chronic pain: Predictors and relationship to compliance. The Clinical Journal of Pain, 21(4), 302-310.

Landstingsförbundet. (2005). Statistisk årsbok för landsting. Stockholm:

Landstingsförbundet.

Linton, S. J., Keefe, F. J., Jansson, O., \& Aslaksen, K. (1992). The outcome evaluation questionnaire: Preliminary findings from a sample of acute pain patients. Scandinavian Journal of Behaviour Therapy, 21, 163-170.

McCracken, L. M. (1998). Learning to live with the pain: Acceptance of pain predicts adjustment in persons with chronic pain. Pain, 74(1), 21-27.

McCracken, L. M., Carson, J. W., Eccleston, C., \& Keefe, F. J. (2004a). Acceptance and change in the context of chronic pain. Pain, 109(1-2), 4-7.

McCracken, L. M., \& Eccleston, C. (2003). Coping or acceptance: What to do about chronic pain? Pain, 105(1-2), 197-204. 
McCracken, L. M., \& Eccleston, C. (2005). A prospective study of acceptance of pain and patient functioning with chronic pain. Pain, 118(1-2), 164-169.

McCracken, L. M., \& Gross, R. T. (1993). Does anxiety affect coping with chronic pain? The Clinical Journal of Pain, 9(4), 253-259.

McCracken, L. M., Spertus, I. L., Janeck, A. S., Sinclair, D., \& Wetzel, F. T. (1999). Behavioral dimensions of adjustment in persons with chronic pain: Pain-related anxiety and acceptance. Pain, 80(1-2), 283-289.

McCracken, L. M., \& Turk, D. C. (2002). Behavioral and cognitive-behavioral treatment for chronic pain: Outcome, predictors of outcome, and treatment process. Spine, 27(22), 2564-2573.

McCracken, L. M., Vowles, K. E., \& Eccleston, C. (2004b). Acceptance of chronic pain: Component analysis and a revised assessment method. Pain, 107(1-2), 159.

McCracken, L. M., Vowles, K. E., \& Eccleston, C. (2005). Acceptance-based treatment for persons with complex, long standing chronic pain: A preliminary analysis of treatment outcome in comparison to a waiting phase. Behaviour Research and Therapy, 43(10), 1335-1346.

Morley, S., Eccleston, C., \& Williams, A. (1999). Systematic review and meta-analysis of randomized controlled trials of cognitive behaviour therapy and behaviour therapy for chronic pain in adults, excluding headache. Pain, 80(1-2), 1-13.

Ostelo, R. W., van Tulder, M. W., Vlaeyen, J. W., Linton, S. J., Morley, S. J., \& Assendelft, W. J. (2005). Behavioural treatment for chronic low-back pain. Cochrane Database of Systematic Reviews(1), CD002014.

Pavot, W., Diener, E., Colvin, C. R., \& Sandvik, E. (1991). Further validation of the satisfaction with life scale: Evidence for the cross-method convergence of wellbeing measures. J Pers Assess, 57(1), 149-161.

Roberts, A. (n.d.). Quotes from Talcott Parsons. Retrieved November 17, 2005, from http://www.mdx.ac.uk/www/study/xpar.htm

Statens beredning för medicinsk utvärdering. (2000). Ont i ryggen, ont i nacken: En evidensbaserad kunskapssammanställning. Stockholm: Statens beredning för medicinsk utvärdering.

Statens beredning för medicinsk utvärdering. (2003). Sjukskrivning - orsaker, konsekvenser och praxis: En systematisk litteraturöversikt. Stockholm: Statens beredning för medicinsk utvärdering. 
Turk, D. C., \& Rudy, T. E. (1990). Neglected factors in chronic pain treatment outcome studies--referral patterns, failure to enter treatment, and attrition. Pain, 43(1), 7-25.

Viane, I., Crombez, G., Eccleston, C., Poppe, C., Devulder, J., Van Houdenhove, B., et al. (2003). Acceptance of pain is an independent predictor of mental well-being in patients with chronic pain: Empirical evidence and reappraisal. Pain, 106(1-2), 6572.

Vlaeyen, J. W., \& Linton, S. J. (2000). Fear-avoidance and its consequences in chronic musculoskeletal pain: A state of the art. Pain, 85(3), 317-332.

Vlaeyen, J. W., \& Morley, S. (2005). Cognitive-behavioral treatments for chronic pain: What works for whom? The Clinical Journal of Pain, 21(1), 1-8.

Wilson, G. T. (1996). Manual-based treatments: The clinical application of research findings. Behaviour Research and Therapy, 34(4), 295-314. 


\title{
BEHANDLINGSMANUAL
}

Korttids kognitiv beteendeterapeutisk intervention med inriktning Acceptance and Commitment Therapy för smärta

Söderhamnsprojektet 2005

Lotsen - att hamna rätt i sjukvården och livet

\author{
Av: \\ JoAnne Dahl \\ Magnus Johansson \\ Malin Lindbäck \\ Tobias Lundgren \\ Michael Wagner
}

2005-04-20

Uppsala Universitet

OBS!! Detta är ett utkast, inget färdigt material. Manualen bearbetas och utprövas inom projektet. Denna manual får inte kopieras, spridas eller användas av utomstående innan projektets avslutande 2006-05. Kontakta någon av ovanstående för frågor. 
Appendix A

\section{Innehållsförteckning:}

Sida:

ARBETSSÄTT

3

SESSION 1- Values

6

SESSION 2- Commitment

9

SESSION 3- Commitment, val och kontroll 15

SESSION 4- Individuell inriktning och avslut 20

REFERENSER 22

BILAGOR:

1- Upplägg för terapin 23

2- Hemuppgift 1

24

3- Hemuppgift 2

28

4- Hemuppgift 3

41

5- Sammanfattning av terapiarbetet

43 


\title{
ARBETSSÄTT
}

\author{
Behandlingsinriktning \\ Förhållningssätt som terapeut \\ Förhållningssätt i grupp \\ Praktiska detaljer i arbetet \\ Om annat vårdbehov finns \\ Journalföring
}

\section{Behandlingsinriktning}

Denna manual är utformad efter Acceptance and Commitment Theraphy, en inriktning inom Kognitiv Beteende Terapi. Särskilt fokus läggs på individens eget ansvarstagande och fria vilja. De strategier vi använder oss av har acceptans som ett centralt fokus. Vi utgår i behandlingen från klientens egna värderingar och mål som vi tar upp tidigt $\mathrm{i}$ behandlingen. Att acceptera sitt liv med sina förutsättningar och att aktivt engagera sig i sitt liv och föra det mot ens egna mål och värderingar är något utav huvudprinciperna. Även att känna och acceptera alla känslor och tankar man har som människa, och ändå se sin frihet i att välja sin egen framtid. Medvetennärvaro (mindfulness) och hur man ser på sig själv och sitt liv är andra viktiga komponenter.

En hypotes vi har när vi arbetar med livsvärderingar är att problem och besvär som smärta och upplevelsen av smärta kan orsakas eller förstärkas av att man stänger av vissa områden av ens liv. När en person inte får leva ut alla delar av sig själv och inte ser möjligheter att förverkliga sig själv, utan skär bort vissa områden. Som ex. en kvinna som har satsat all sin energi på endast sin familj eller sitt arbete. Detta sätt att se på livet gör att man skapar regler för hur man får/bör vara som människa och vad man ska/bör vilja. Personen har ofta skapat endast ett få tal roller istället för att fortsätta utveckla sig själv inom alla områden i livet. Vi tror också att smärtan som upplevelse kan ha fått en stor central roll i dessa personers liv, helt förståeligt. Att personen formar sitt liv och anpassar sig efter smärtupplevelsen. Smärtan har blivit en del av personens identitet, livsbild och självbild. Smärtan måste kontrolleras till varje pris, och står som ett oöverstigligt hinder mellan personen och det liv som denna människa skulle vilja leva. De livsområden vi ofta talar om är intima relationer, familjerelationer, socialt liv, arbete, utbildning och personlig utveckling, fritid, andlighet och harmoni, samhällsengagemang, egenvård och föräldraskap. Detta ser vi som områden som är centrala i många människors liv.

\section{Förhållningssätt som terapeut}

Terapeuten sitter nära, är engagerad, deltagande, närvarande och empatisk. Det är viktigt att man bemöter klienten med stor respekt och känsla. De har säkert blivit ifrågasatt och misstrodda många gånger i sitt liv, och fruktar kanske att vi nu också ska lägga på dem skuld, att deras smärta är deras eget fel eller beror på psykiska problem. Vi använder gärna förhållningsätt från motivational interviewing. Att själv som terapeut vara mindful om sin egen känsla och upplevelse är viktigt. Att man känner vilka områden som är känsliga och vågar gå in i dessa med klienten med respekt och förståelse för denne, men att man samtidigt är uppmärksam på sin egen känsla. Rädsla för att ta risker som terapeut är okej, så länge man känner att man inte tvingar sig. Vi tycker det är viktigt att värna om sin egen stil och känslighet som terapeut. Som terapeuter så 
stödjer vi också varandra i arbetet i nära kontakt med handledaren, med förtroende, respekt och flexibilitet för varandra.

För att vara effektiv och närvarande i nuet som terapeut är det viktigt att gå in i det som händer i rummet, det som klienten upplever just då. Ta upp och exponera känslor som passerar strax under ytan eller som är mer tydligt påtagliga under samtalet. Ge acceptans som terapeut till allt hos klienten. Tillåt allt att komma fram och existera. Både ont och gott. Det är viktigt att också komma ihåg att ta in information från klientens kroppsspråk, och ta upp det man ser där under sessionen. I utövandet av ACT-terapi är det viktigt att inte fastna i innehållet av det klienten säger, utan fokusera på funktionen. Inte fastna i deras "stories". De har verkligen förståeliga skäl till att undvika vissa saker och skära ner områden i sitt liv. Men vi vill visa för dem funktionen av deras beteenden och val.

\section{Förhållningssätt i grupp}

I grupp är vi två terapeuter samtidigt med 5-8 klienter. Här är det viktigt att vårda samarbetet, se till att vi tillför och stödjer varandra som terapeuter. Co-terapeuten får inte störa, säga emot eller ifrågasätta den terapeut som är aktivt ledande för stunden. Visa förtroende för varandra i arbetet och stötta. Arbetet under sessionen utvecklas framåt tillsammans, klienter och terapeuter. Coterapeuten stödjer arbetet genom att modellera övningarna för de andra deltagarna och vara en aktiv medverkare i gruppen. Visa vad som förväntas av dem i rollspel och övningar genom att själv delta och agera. Det gäller att ha med klienterna, inled varje övning med att förklara hur det ska gå till och vad den ska vara bra för. Motivera övningen och gör det lätt för klienten att förstå poängen med den. Efter varje övning bör man öppna för kommentarer och frågor.

Som terapeut bör man vara naturlig, mänsklig och avslappnad. Vara sig själv, på samma sätt som med en individuell klient. Man bör våga klanta sig, göra fel, våga visa sig själv som en vanlig människa med styrkor och brister. Tala ledig och uppmuntra gruppen att öppna sig och aktivt deltaga. Var närvarande, deltagande, våga närma dig deltagarna. Våga ta i känslor som kommer fram och välkomna även tyngre negativa känslor som rädsla, sorg och smärta. Visa att det är acceptabelt och naturligt. Se människorna i rummet. Ta upp de känslor som kommer. Vi vet att det här är jobbigt, den smärta du känner, men vi finns med dig här för att hjälpa dig igenom detta, det är okej att känna smärta och sorg och rädsla. Den fär finnas.

Ett tips om någon tar mycket plats och söker mycket uppmärksamhet och irriterar dig som terapeut är att en av terapeuterna försöker närma dig denna person rent fysiskt, så att terapeuten kan ge mer uppmärksamhet, närhet och bättre kontrollera denne inom gruppen. Exempelvis genom att sitta nära denna person i gruppen. Personen ifråga behöver kanske bli sedd mycket.

\section{Praktiska detaljer i arbetet}

Efter varje session antecknar terapeuten stöd ord efter egna önskemål för att ha en bild av vad som blev gjort med denna klienten i terapin, om några problem uppstod eller om det är något man bör ta upp igen nästa individuella session. Det är viktigt att alla punkter på agendan täcks något så när med alla deltagare. Det dröjer tre veckor till nästa individuella träff, och det är klientens sista. Anteckningar är konfidentiella, förvaras säkert och är avidentifierade och ingen personlig identifierande information om klienten utelämnas. Vid ett antal tillfällen under arbetets gång har terapeuterna träffar med handledaren där man diskuterar hur det går, att en likformighet i behandling hålls och man stödjer varandra i sin uppgift. Handledaren kan även kontaktas hela tiden vid behov. Vid gruppterapin håller de två samarbetande terapeuterna en öppen dialog 
tillsammans kring sitt samarbete före och efter sessionerna. Ger varandra tips och stöd och utvärderar hur det går.

\section{Om annat vårdbehov finns}

Om det kommer upp problem som att personen har någon allvarlig fysisk sjukdom som de ej sökt medicinsk vårt för, lider av grav depression eller gravare psykiatriska sjukdomar så rekommenderar vi klienten att även söka kontakt med läkare eller psykiatriker. På samma sätt kan de även söka kontakt med sjukgymnast och andra former av vård och behandling allt efter egna önskemål, utöver vår behandling. Detta alternativ står alltid öppet, vi kan förmedla viss kontakt om klara behov av hjälp med detta föreligger, men beblandar oss annars inte i detta hjälp sökande. Det hör till "treatment as usual" delen i forskningsupplägget, dvs. att all vanlig vård som finns tillgänglig i samhället finns även tillgänglig för deltagarna att söka bäst de vill. Detta ger mer validitet till studien, och möjliggör för alla att söka den hjälp de önskar och tror sig behöva. Den vanliga vägen via deras vårdcentral är att föredra. Men om det föreligger risk för suicid eller mer akuta problem kontaktas behandlingsansvarig omedelbart, och vi försöker tillsammans med klienten söker vi upp läkare som kan omhänderta och skriva in klienten.

\section{Journalföring}

Journal förs enligt vedertagna lagar och föreskrifter på den behandlingsansvariga vårdcentralen där arbetet sker, av terapeuterna med undertecknande av handledaren. 
Appendix A

\section{SESSION 1 - Values}

Individuell session med en terapeut, ca. 1,5 timmar.

\section{Inledning \\ Värderingar - analys av var klienten står idag \\ Kreativ hopplöshet \\ Hemläxa \\ Andra lämpliga övningar och metaforer för första sessionen}

Mål: Formell information. Värderingar. Presentera hemläxan-livskompassen. "Jag vill .. men.. meningar”. Lista hinder. Fånga deras känslor. Kreativ hopplöshet. Vilket liv vill de leva? Grunda den terapeutiska relationen genom att visa närvaro, acceptans och förståelse. Minska fusion med smärtan. Hitta individuella målsättningar med behandlingen.

De individuella sessionerna ska hålla samma ramar för alla klienter, ungefär samma innehåll och behandla samma områden. Men vi anser också att individuell flexibilitet är viktigt. Att man i rummet kan ta upp det som känns viktigt och aktuellt, det som kommer fram, gå djupare in i känslor klienten får, vara en seende och närvarande terapeut som skapar en god kontakt och relation med klienten. Eftersom både terapeut och klient är skiljda individer och båda påverkar situationen kommer en viss variation alltid att finnas i behandlingen. Denna flexibilitet kan ses som en styrka. Personliga variationer hur man vandrar med klienten på vägen genom den terapeutiska snårskogen och ändå passerar samma kontroller längs med banan.

\section{Inledning}

Klienten välkomnas. Terapeuten presenterar sig och det arbete som kommer att ske under behandlingen. Tar upp tystnadsplikt och pratar om hur de följande sessionerna kommer att se ut, möjligen en kort agenda för terapiarbetet. Nämner återigen för klienten att de följande två sessionerna kommer vara i grupp tillsammans med ytterligare en terapeut, och att behandlingen sen avslutas med ytterligare en individuell session. Förklarar att vi vet att de har sökt till det här projektet för sina smärtproblem och att vi här ska arbeta med hur deras liv ser ut kring smärtproblemen, men även utöver smärtan.

\section{Värderingar - analys av var klienten står idag (Values)}

Man bör ha en bild av livskompassen uppritad på ett papper eller en tavla, så man kan visa på denna under samtalet. I samtal med klienten ska vi här få fram vad denne värderar i livet, tycker är viktigt och centralt. Hur personen skulle vilja vara, skulle vilja ha det och vad personen skulle vilja sträva efter att uppnå. Centrala livsvärderingar och mål. Hitta en väg i livet som man vill gå. Ett mål här är att finna en central och djup värdering för individen som man sen kan utgå från och söka vad som hindrar klienten från att ha detta nu. Samt att tillsammans lista några "jag vill... men..." meningar och några av de hinder klienten tar upp. Detta får klienten även jobba vidare med själv i hemläxan (se bilaga).

Exempel på frågor: Hur har du det just nu i ditt liv? Vad vill du med ditt liv? Hur skulle du vilja leva? Vad skulle du vilja ha tillbaka i ditt liv? Vad hindrar dig från att göra detta, uppsöka detta? 
Vad hindrar smärtan dig från? Vad hindrar dig från att leva det liv du vill leva? Saknar du något i ditt liv? Vad fick dig att söka dig hit? Var står du nu? Vad har hänt med ditt liv?

Vad vill smärtan dig? Ta in de känslor, tankar och den smärta som hindrar dig. Vad är du rädd för i detta? Ta fram den rädslan, sorgen.

Vad leder dessa till? Vad ser du för mönster i det här?

Finns det en känsla eller tanke inom dig, kopplat till smärtan, att du inte duger och är tillräcklig?

Hur känns den tanken, den känslan? Vad leder det till?

- Värderingar (starta VLQ)

- Hinder (lista)

- "Jag vill...., men..." meningar (lista). (Vad leder detta till?)

- Vad har du gjort hittills för att hantera/kontrollera smärtan/den jobbiga känslan?(lista strategier)

- Hur har det fungerat? Vad ser du för mönster?

\section{Kreativ hopplöshet}

(Creative hopelessness, willingness)

Den funktionella analysen kan ofta tydligt visa på att de har försök på många sätt att bli av med sin smärta och sina jobbiga känslor. Men att de bara blir värre och värre ju mer de försöker kontroller eller undvika dem. Dvs. inte acceptera dem. Vi kan tex. utifrån listan av deras tidigare strategier pressenterar för dem att vi ser här hur de har kämpat med det jobbiga och försökt på helt förståeliga och naturliga sätt att komma undan det jobbiga. Men att detta bara har fört dem längre från det liv de vill leva, och gjort smärtan och rädslan större och ökat kontrollbeteendena. Vi eftersträvar här lite en aha-upplevelse. De ska se att smärtan har fått styra deras liv, även om den egentligen bara är en kroppslig reaktion, och deras liv innehåller så mycket mer än smärta.

Vid insikt av detta är det viktigt att som terapeut acceptera och ta emot de känslor som detta kan innebära för klienten. Vi kan sedan berätta att vi ser alla de här sätten de har kämpat mot känslan, vi vet att de väl känner till den kampen och vet vad den innebär. Vi ser här att undvikandet inte leder dit de vill, och frågar om de är villig att känna den här känslan för att komma närmare det liv de vill leva? Förslagsvis kan man presentera valet som valet mellan två paket. (ex. levande eller död häst metaforen)

$\ddot{A r} d u$ villig att känna smärta, rädsla, obehag och ta risker att utsätta dig för detta, för att komma närmare det liv du vill leva, det liv du värderar, det liv du har beskrivit här för mig? Jag tror att de värderingarna är livsviktiga för dig, din hälsa och ditt välmående. Skulle du vara villig att ha med dig den här känslan i ditt liv, med det som den vill säga dig, acceptera att den finns där med dig också? Är du villig att ha detta?

Här eftersträvar vi nu willingness till behandlingen och till deras livsvärderingar.

\section{Hemläxa}

(Values)

Hemläxan ges ut och förklaras. Kopplas även till det som vi har gått igenom idag under sessionen. De ska fylla i livskompassen, där de anger hur de skulle vilja ha sitt liv, hur de skulle vilja vara och vilka hinder som står i vägen. Försök vara tydlig med att det man söker på livsområdena är djupa värderingar. Att man kan fråga vidare "varför vill jag ha det så?" tills man hittar en djup central värdering som är viktig för en. De kan även fortsätta på "vill...men" listan. De ifyllda formulären bör sedan klienten spara själv för det fortsätta arbetet längre fram. 
Appendix A

\section{Andra lämpliga övningar och metaforer för första sessionen}

Exponeringsövning för känslan som de undviker:

Ta in känslan. Låta rädslan och smärtan fylla klienten och rummet. Accetera den. Gå in $i$ den känslan som hindrar dig. Känn den. Ser det som kommer upp i ditt huvud, tillåt tankar och känslor att komma. Kan du beskriva den känslan? (ex. fysikalisering) Vad vill känslan?Hur känns den här tanken? Hur känns den här känslan?

Kan även här exponera för fysisk smärta. Att de ska stå eller sitta på ett obekvämt sätt som ger dem smärta, och verkligen gå in i och känna den smärtan.

Mindfulness övning:

Avslappning. Andning. Närvaro. Känna känslor. Minnen.

Tiger metaforen:

Hur rädslan har fått kontrollen på hela deras liv. Allt går åt till att kontrollera och undvika den stora vilda hungriga tigern.

Levande och döda hästen:

Om de kan välja vill de satsa på de sätt som de vet vad de leder till. Kontroll metoderna. Eller är de beredd att chansa på livet i riktning mot sina värderingar även om det kan innebära motgångar, förluster och smärta?

Förenklad funktionell analys:

Efter att ha fått fram vad personen saknar i livet och vad som hindrar dem från att ha detta kan det var lämpligt att gå in på den jobbiga känslan och se hur klienten har hanterat den. Vad har de gjort för att hantera känslan. Undvikanden, bortförklaringar, rationalisering, kontroll strategier, etc. Sedan undrar vi hur detta har fungerat. Om man vill göra det tydligt kan de listas och man kan åskådliggöra på listan hur varje sak har fungerat på kort och lång sikt. Vad hände med känslan.

Clean \& dirty discomfort:

Känslor man tillåter sig att ha och inte tillåter sig att ha. Att acceptera ett obehag eller låta ett obehag styra ens liv genom att undvika det. Vad vill smärtan dig? Den är en skyddsmekanism som vill dig väl. Är du villig att ta emot den, ha den, känna den?

Gräva hålet djupar och djupare (the man in the hole):

Metaforen om spaden och att bara gräva djupare och djupare, inte se vart man kommer. Om grävandet är hopplöst, vad ska du då göra? Vad innebär det här? Vill du få en ny spade av mig?

\section{File-drawer övningen:}

Utgå från ett minne som klienten får gå in i och beskriva. Kan leda till en exponeringsövning för känslan. 
Appendix A

\title{
SESSION 2 - Commitment \\ Gruppträff 5-8 personer, två terapeuter, ca. 3 timmar.
}

\author{
Inledning \\ Mindfulness med kreativ hopplöshet \\ Hemlighetsövningen \\ Begravningsövningen \\ Bussmetaforen \\ Hemläxa \\ Public-commitment
}

Mål: SWLS. Pröva medveten närvaro, känna känslor. Acceptans. Begravningsövningen. Bussmetaforen. Förklara hemläxan bulls eye (commitment). Public-commitment.

\section{Inledning}

Hälsa alla välkomna. Pressentera er som terapeuter, och gruppdeltagarna för varandra. Ta upp etiska frågor för gruppen och prata om tystnadsplikt. Ex. Alla är här för samma orsak och är här för att hjälpa varandra på vägen i livet. Vi jobbar här som grupp tillsammans, och det är viktigt att ni känner ett förtroende för varandra här i rummet. Det kan hända att det kommer upp privata och känsliga saker här under träffen och det är viktigt att vi alla respekterar varandra som individer här. Att alla också respekterar att det som sägs här i rummet stannar här mellan oss, och att vi har tystnadsplikt mot andra utomstående. Fråga om alla kan respektera detta? Gör sedan en återkoppling till den första individuella träffen där vi pratade om värderingar och vad som hindrar dig i livet och vad det har lett till. Ta även upp hemläxan som handlade om värderingar och hur de vill vara och leva sitt liv. Ge en kort agenda för dagen och det fortsatta terapi arbetet, vad som kommer att behandlas under vårt arbete tillsammans. Sedan inleder vi terapiarbetet med att fylla i SWLS igen (för Magnus mätning av hur den utvecklas under behandling).

\section{Mindfulness med kreativ hopplöshet}

(Acceptance, creative hopelessness)

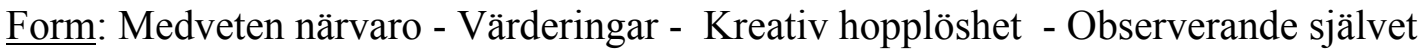

Vi tänkte börja dagen med en övning i medveten närvaro. Förklara medveten närvaro som begrepp (att vara här i nuet, närvarande och att verkligen känna alla tankar, känslor och minnen som man känner).

Sätt dig bekvämt. Slut ögonen om ni vill, och börja slappna av i kroppen. Fokusera på din andning. Tänk på hur du andas in, och andas ut. Hur luft strömmar in i dina lungor och din kropp, och hur du sen andas ut den luft du inte behöver. När du andas ut, känn hur din kropp slappnar av mer och mer, hur du blir tyngre på stolen där du sitter. Fortsätt fokusera på din andning, samtidigt som du tänker på var du är. Här i rummet. I söderhamn. I världen. På jorden. Att du ser dig själv utifrån. Se dig själv sitta i det här rummet. Här på stolen. Du är den du är, här och nu. Låt dina tankar vandra dit de vill vandra. Låt de känslor du känner komma till dig. Se det du ser. Hör det du hör. Känn det du känner. Bara var här i nuet, med dig själv. Och känn de känslor som kommer över dig. 
Appendix A

Jag vill nu att du ska låta tankarna vandra till de områden i livet som vi talade om förra gången. Hur du vill vara. Vad som är viktigt för dig. Vad du vill ha ut av ditt liv. Hur vill du ha det? Vad är din riktning? Vi talade också förra gången om vad som hindrar dig. Vad du är rädd för.

Smärtan. Att inte duga. Att bli lämnad. Sårad. Jag vill att du tänker dig in i din livssituation och hur du skulle vilja ha det. Hur du skulle vilja känna dig. Må fysiskt och psykiskt. Hur du skulle vilja ha din fritid, ditt arbete, dina relationer. .... När du nu tänker på vad som har hänt dig. Var du befinner dig nu istället. Allt du har försökt för att bli av med smärtan och andra obehagliga känslor. Jag vill att du känner den känslan av hopplöshet $i$ den här ändlösa kampen. Hur du än kämpar, kommer du bara längre och längre från det liv du önskar. Jag vill att du går in i den här känslan. Hopplösheten. Uppgivenheten. Sorgen. Smärtan. Även om den är jobbig och du inte vill ha den. Ta en minut, och bara känn den känslan. Släpp fram den. Låt den existera. Den är också en del av dig....

Se sen dig själv igen. Vem du är nu, som sitter här och iakttar den här känslan. Se dig själv, här $i$ rummet, med gruppen. Se dig själv nu med alla dina tankar, känslor, minnen. Med din kropp, dina rädslor, din smärta, din vilja. Alla delar av dig. Känn din andning. Kraften inom dig själv. Viljan som finns där, bland alla andra känslor och tankar. Viljan som tog dig hit. Att du har makt över ditt eget liv.... Jag vill att du långsamt börjar komma tillbaka hit till rummet, och här och nu. Ta några djupa andetag, sträck på dig, och öppna ögonen.....

Hur kändes den här övningen? Frågor? Något som ni vill dela med er av? Något som ni undrar över?

\section{Hemlighetsövningen}

(Values)

Jag vill att ni nu efter detta tänker efter var ni står i ert liv, var ni vill komma och vad som har hindrat er på vägen. Som vi har pratat om tidigare. Detta kopplar man till hemläxan och värderingkompassen. Ev. rita upp en kompass som alla kan titta på. Sitter tyst en stund och alla får tänka efter för sig själv. (Detta kommer vi sen att återkomma till som avslutning och publiccommitment). Här kan man själv ge exempel. Tex. Min största hemlighet just nu är att jag är rädd att jag som ny student och oerfaren terapeut inte ska vara tillräckligt kompetent för att hjälpa er här, och att ni ska tycka jag gör ett dåligt jobb. Men jag vill verkligen hjälpa och tillföra något till er alla. Det är därför jag är här. Det är ett exempel på detta.

\section{Begravningsövningen}

(Acceptance, values, willingness)

Olika förslag på introduktion av begravningsövningen: (Bör innehålla meningen med övningen, diskrepansen mellan det man göra och det man vill. Att man har en möjlighet att engagera sig $\mathrm{i}$ sina önskningar och mål, kan ta steg mot detta.)

- Nelson Mandela har sagt en berömd kommentar; att människans största rädsla är inte att vara inkompetent, utan att vara kompetent. Att vi kan leva ut våra drömmar. Att vi är skyldiga oss själva att leva ut våra önskningar, och förverkliga våra värderingar. Att vi kan välja. Det är ett ansvarsfullt jobb, att vara kompetent.

- Ofta vet man mycket väl vad man borde göra, vad man ville göra, hur man skulle vilja ha det. Men något kommer liksom emellan, och man gör inte faktiskt så, eller man skjuter det på framtiden, kommer med andra tankar och förklaringar. 
- Många av er känner kanske till Charles Dickens julsaga som brukar gå på tv vid jul. Den handlar om en man som fär följa med ett spöke in i framtiden och se hur hans liv ser ut, och sen vaknar han upp och fär en andra chans att leva sitt liv som han vill leva. Jag tänkte att vi skulle göra en övning här där vi illustrerar detta.

- Alla har ni säkert varit med om någon svår och livsomvälvande händelse. Som till exempel när någon nära går bort eller någon blir sjuk. Då ser man ofta vad som är viktigt här $i$ livet. Jag skulle vilja göra en övning där vi försöker illustrera detta tillsammans.

Begravningen:

Då skulle jag vilja ha en person som kan spela huvudpersonen här i det här. Välja en och fråga om denna kan tänka sig göra övningen tillsammans med alla andra.

Jag vill att ni andra ska hjälpa till här och stödja xxx här i övningen. Hjälpa honom/henne och mig med detta och skapa det utrymme som behövs här för att göra övningen. Vi behöver alla samarbeta för att genomföra det här tillsammans på ett bra sätt. Och du, xxx, bestämmer själv hur mycket du vill berätta och dela med dig av dina känslor och tankar här hela tiden.

Vi ska nu spela din begravning, som om du hade gått bort nu som du lever idag. Jag vill att du ska tänka på vilka personer du tror kommer att vara här på din begravning och nämna för oss några av dessa från olika områden i ditt liv. Vilka tror du skulle vara där? (om de inte vet någon så får de även ta dit folk som inte längre är i livet, folk som inte skulle vilja vara där men som ändå personen tar dit nu, påhittade personer som personen inte har träffat än i livet men som kommer nu)...... Sen vill jag också bjuda in din kropp och din själ här på din begravning. Berätta eventuellt hur övningen kommer se ut i stort innan vi startar. Åskådliggör övningen genom att dela ut roller till andra deltagare och placera alla som att de satt på en begravning vid en kista, med deltagaren och terapeuten i mitten. Skaffa någon representant från personens olika områden och roller i livet, ex. familjemedlem, arbetskamrat, vän, partner, barn, granne, etc. I fall personen nämner ex. flera syskon så fråga i fall det skulle gå bra att vi bara repressenterar en av dess här, eller om de kan repressenteras av en person bara.

Då vill jag att du tänker dig att du är här på din begravning, på personerna som är här, och hur du själv kan gå runt nu osynlig och se och möta människorna här, vi är alla här för att stödja dig i detta, och alla är här nu för din skull.... Jag vill då att vi tillsammans går fram till den första personen här då, din xxxx. Jag vill att du tänker dig denna person, ser denna in i ögonen, och tänker vad den här personen skulle tänka om ditt liv. Jag vill att du för oss beskriver det värsta denna person skulle kunna tänka om dig, det du mest fruktar att de skulle tänka om dig och ditt liv. Vad är det? Be personen som spelar denna roll att komma ihåg det som deltagaren sa..... Då går vi vidare här $i$ rummet, vi går vidare till din xxxx här. Jag vill även nu att du ser denne $i$ ögonen och tänker det värsta denne skulle kunna tänka om dig och ditt liv här på din begravning......osv.. runt rummet, tills deltagaren har mött alla inklusive sin kropp och själ. Följ med personen runt, var ett stöd och skydd på vägen runt i rummet. Nu har vi gått igenom vilka hemska saker dina nära och kära skulle kunna säga och tänka här. Kistan och alla står här nu. Alla kommer nu att säga till dig vad du fruktar att de ska tänka om dig här .... Ordet går runt och alla får säga det som deltagaren sa till dem tidigare. Uttrycker rädslan och tankarna verbalt som om de var den personen, spelar sin roll. Pausa lite efter varvet och låt deltagaren känna känslan och sina tankar.

$N u$ vill jag att vi ska gå varvet runt igen och att du ska säga till varje person hur du vill att det ska vara mellan er, vad du vill att de ska säga, och vad du ska göra som första steg för att ta er relation och dig dit. Vi börjar här igen med xxxx då. Se han/henne i ögonen, och säg vad du vill 
säga till honom/henne om hur du vill ha det och det som har blivit sagt, och vad du vill göra nu för att det ska bli så. Klienten får möta alla igen och uttrycka sin värdering och känsla och ett "comittment" för att börja sin väg dit. Försök få det till ganska konkreta ageranden som klienten kan ta aktivt redan nu. Om klienten absolut inte vill säga detta framför gruppen, kan man be dem kanske uttrycka något, eller tänka det tyst. Hur kändes detta? Kan ni andra leva er in i samma situation och tänka er hur det skulle vara för er, i samma situation, på er egen begravning. Vad ni fruktar att andra skulle tänka om er och ert liv, och hur ni vill att de skulle tänka och beskriva er och ert liv. Vad kan ni göra redan idag för att ta er mot detta, vara den person ni vill vara, den person ni vill att de ska känna och tänka på vid detta tillfälle? Tänka att ni gör ett "committment" ett engagemang mot det liv ni vill ha och den person ni vill vara och faktiskt är, bara du själv kan välja den vägen att gå. Vad tänker ni om detta?

Eventuellt ta en paus, bjud på frukt eller något.

\section{Bussmetaforen}

(Defusion, acceptance)

Nu har vi pratat om era värderingar, hopplösheten ni känner angående hur ert liv ser ut, hur ni skulle vilja ha det, och lite om vad man kan göra för att börja ta sig dit. Vi ska nu fortsätta på det temat hur man kan ta sig dit man vill, och hur ni kan förhålla er till dessa tankar och känslor. Inleder med att förklara övningen och meningen med den. Välj ut en ny person som tillfrågas om att vara huvudaktör i övningen.

Vi ska illustrera vad som händer när man vill något, vill göra något, och nästan är på gång att göra det, men ändå inte kommer dit. Vi ska åka buss, bussen representerar ditt liv och du är chauffören längst fram. Sedan kommer vi att fylla bussen med medpassagerare, din historia, dina erfarenheter, dina minnen, dina känslor, dina tankar. Dina jobbiga tankar och känslor kommer nu att spelas av de andra personerna här. Vi ska här pröva att förhålla sig till dem på tre olika sätt.

Då vill jag börja med att fråga dig om en inriktning som du skulle vilja engagera dig $i$, men som du inte gör idag? Till exempel hur du skulle vill ha det $i$ en relation, ett fritidintresse du skulle vilja utöva som du inte gör idag, ett jobb du skulle vilja söka som du inte söker etc. Gärna något från din värderingskompass som du hade som hemläxa. ...

Vad är det som hindrar dig från detta? Vilka tankar kommer upp när du vill göra detta? .... Terapeuten utser en person att spela varje roll som en tanke eller känsla som hindrar klienten, och placera ut de andra deltagarna utspridda framför den väg som klienten ska färdas mot. Du har din riktning här, ditt fokus, det du vill göra, du ska köra din buss dit. Visar klienten ett mål som man ska gå emot. De här personerna kommer nu att komma upp framför dig på vägen och fråga dig "vart är du påväg nu, vad har du tänkt dig nu". De är dina tankar, dina minnen, din historia och dina erfarenheter. Kom ihåg att alla här bara spelar roller för att hjälpa varandra här $i$ arbetet. Tänk på att det är din historia, dina erfarenheter, dina tankar. Alla här i gruppen kanske känner igen dem och kan spela ut dem, hitta på kring dem lite, men med respekt för att det är xxx's tankar och känslor här som vi åskådliggör. Det kan kännas väldigt träffande och kanske jobbigt att möta dessa tankar och känslor fysiskt.

Först vill jag att du ska möta dem här på vägen och så ska du göra det du brukar göra. Vad brukar du göra när dessa tankar kommer fram? .... Undvikande, kompromisser. När du kör din buss mot dina mål så brukar dessa tankar och känslor komma fram och störa dig, varna dig, vi ska spela det. Då börjar vi vår färd. Du ska bemöta tanken och svara den vart du är påväg och 
sen göra som du brukar, så kommer jag sen att vrida på dig lite för att åskådliggöra vad som händer med din riktning när du gör som du brukar göra, dvs. kompromissa eller undvika, byta riktning. Man börjar spelet. Klienten kommer ingen vart längs den riktning ni har utsatt som mål. Tankarna går runt som i en cirkeln kring klienten och alltid kommer en ny framför klienten och hindrar denne. ... Vad hände här med din riktning?...

$N u$ vill jag att vi ska ta tag $i$ det här problemet ordentligt. Din uppgift denna gång är att argumentera med dem och svara dem, säga emot dem. Du vill ha bort dem frän bussen. Drar àt handbromsen och vill få av dem, bort dem från ditt liv. Argumentera med tankarna. Så ser vi vad som händer. Terapeuten och co-terapeuten får tankarna att gå runt snabbare och snabbare runt klienten och argumentera vilt. Så klienten inte får någon chans att gå dit han/hon vill. Hur gick det denna gång att färdas mot ditt mål?....

Då vill jag att vi ska pröva en sista variant. Tankarna kommer nu att komma framför dig på samma sätt. Men du ska inte argumentera mot dem och försöka få bort dem. Du ska inte heller försöka göra som de säger, kompromissa eller vända dig bort. Utan du lägger en hand på deras axel, lyssnar och visar dem att du förstår och har hört vad de sagt, du accepterar dem, men håller ändå din riktning. Man spelar igen. De andra deltagarna går runt nu igen. Men klienten står kvar mer på stället och fastnar inte med varje person. Hur gick detta nu?.... Vilka är dessa tankar och känslor? Vad vill de dig egentligen?....

Den här sista gången så lyssnade du på dem, men tillät dem inte att styra dig från kursen. Du tar med dem på din buss, sätter dem här bakom dig. De är med dig på din resa, som en del av dig. De har något de vill säga dig, de vill dig väl, välkomna dem med på din resa.

Här $i$ övningen har vi nu illustrerat olika sätt att förhålla sig till sina tankar och känslor. Vad hände här? Vad var skillnaden i förhållningssätten? Vad säger det er om hur ni kan agera i ert liv? Känner ni andra igen er $i$ detta? .... Inget sätt är rätt eller fel här, men det visar hur man har ett val, kan välja $i$ vilken riktning man vill färdas. Utan att argumentera och försvara, utan att kompromissa och undvika. Men att medvetet göra ett val och ta med sig allt som detta kan innebära.

\section{Hemläxa}

(Commitment)

Sen fortsätter vi med att leda över till hemläxan. Förklara meningen med att ha hemuppgifter. Att det är för deras egen skull, för att öka effekten av behandlingen, och att det är i ute i verkliga livet som en skillnad är intressant, inte bara här i terapi rummet. Det ökar nyttan av behandling. Delar ut papperna för Bullseye övningen. Förklarar commitment-dagboken Bullseye. Koppla den till den tidigare hemläxan, där de har angett sina värderingar och mål i livet. Beskriv hur de varje morgon ska välja ett område som de vill inrikta sig mot, hedra dagen till i en mening. De ska sedan under dagen ta sitt första steg på denna väg, och sedan på kvällen notera hur de gick, om de är påväg mot sitt mål och har börjat närma sig det mer. Förklarar även gravstenen och vad de ska göra med det pappret.

Bullseye- commitment dagbok: Varje morgon ska du skriva ned på ett papper ett område som du vill utveckla och engagera dig $i$ idag. Tänkt ut det första steget du kan göra idag mot detta. Sen på kvällen ser man återigen på papperet och se vad du har åstadkommit idag och hur du kan gå vidare.

Skriva i gravstenen: På ett papper med en bild av en gravsten skriva ned vad som är viktigt för dig själv i livet. Vad man vill att nära och kära ska tänka om en efter ens bortgång. (Bör introduceras till deltagarna med respekt för de känslor som tanken på ens egen bortgång kan ge, 


\section{Appendix A}

förklara att det är en övning för att de ska tänka över sitt liv och hur de vill ha det, att de ska se det positiva i sin kraft och vilja, vad de kan tillföra).

Sen får de fylla i början på bullseye's första papper. De skriver upp ett område, som vi sen ska använda i nästa övning, där de ska ställa sig upp och säga ett commitment till sitt första steg mot detta.

\section{Public-commitment}

\section{(Commitment)}

För att extempligöra commitment får alla avsluta sessionen med att ställa sig upp och säga något de vill göra, men inte gör just nu, och vad de första steg de nu ska ta för att närma sig detta. Tex. Det som de nyss skrev i bullseye-dagboken. Nu vill jag att alla ska få pröva på det som den här dagboken illustrerar. Jag vill att alla tänker efter en stund för sig själv och försöker komma på ett område som ni vill åta er, dedicera er $i$, men som ni ännu inte har tagit tag $i$. Som vi gjorde $i$ början när ni fick tänka efter vad ni ville nu med ert liv och vad som hindrat er. Jag vill sen att alla ska ställa sig upp en och en och säga högt till alla vad ni önskar i livet, vad ni är rädd för gällande detta, vad som hindrar er, och vad ert första steg på vägen mot detta ska bli. Jag och co-terapeuten börjar..... Det här är en fråga som ni kan ställa er hela tiden genom ert liv. Vad vill ni med det här $i$ ert liv? Hur ska ni börja ta er på vägen dit?

Efter detta avslutas sessionen. 
Appendix A

\title{
SESSION 3- Commitment, val och kontroll
}

\author{
Gruppträff 5-8 personer, två terapeuter, ca. 3 timmar.
}

\author{
Mindfulness \\ Kick your buts \\ Schackbrädet \\ Prata om kontroll \\ Rehab-mötet \\ Hemläxa \\ Public-commitment
}

Mål: Mindfulness. Kick your buts. Schackbrädes övningen. Kontroll. Rehab-mötet. Introduktion till hemuppgift. Ett högtidligt public commitment.

\section{Mindfulness}

(Acceptance, defusion)

Vi inriktar oss här på övningen lövet och bäcken, som går över i observatören (observingself).

Nedan följer en variant på hur man kan leda detta.

Vi ska inleda dagens övningar genom medveten närvaro, som vi gjorde förra gången. Jag vill att ni återigen sätter er så bekvämt som möjligt. Slappnar av i kroppen och sluter ögonen.

Koncentrera er på er andning. Hur ni andas in, och andas ut. Hur luft strömmar in i era lungor och sedan pressas ut. Andas djupa lugna andetag. Vi är här nu, och har allt tid $i$ världen att bara vara här, just nu. Du sitter här på stolen och bara andas. Känn hur din kropp är tung och avslappnad. Jag vill att du ska föreställa dig en bäck. En bäck som porlar fram i skogen. Den är bred och ganska djup, rinner fram över stockar och sten $i$ en lugn takt. Det är tidig höst i skogen. Jag vill att du ska föreställa dig att du är bäcken. Du är bäcken som porlar fram över stock och sten. Rinner i din egen takt. Framåt, dit du vill. Dina tankar, känslor, sensationer och minnen är med dig i bäcken. De svävar på dig, flyter runt på ytan. Lika svårfångade och okontrollerbara som löv som flyter runt på ett vattendrag. Är dina tankar och känslor. Men de finns där, de existerar med dig. De passerar, flyter förbi. Du rinner vidare. Du ser dem. Du upplever dem. Och ändå rinner du vidare....

Nu lämnar vi bäcken och jag vill att du ska se dig själv här i rummet igen. Hur du sitter här och nu. Vilka känslor och tankar som flyter genom ditt huvud nu. Lägg märke till att du lägger märke till dina känslor och tankar. Låt varje tanke och känsla komma, välkomna dem, känn dem, se dem. Det är en människa där. På insidan. Som lyssnar på vad jag säger. Det är du. Du är samma person som du har varit hela ditt liv. Du är här nu. ....

Jag vill nu att du ska minnas något som hände förra sommaren. Det kan vara bra eller dåligt, vilket som. Bara ett minne som kommer över dig. Jag vill att du ska se det framför dig. Vad som hände. Hur det var. Vad du kände och tänkte då. Jag vill att du ska se människan som var där. Vem den personen var. Se vad den personen såg. Känn vad den personen kände. Det är du. Det var du då. Känn hur du är den samma som du har varit hela ditt liv.

Nu vill jag att du ska minnas något som hände när du var tonåring. Se situationen framför dig. Som den var då. Som du var då. Vad hände. Hur kände du dig. Vad tänkte du för tankar. Det finns ett samband mellan den person du var då, och den du är nu. Det är du. Du har varit den du är hela ditt liv. Den samma. 
Minns nu något som hände när du var riktigt ung. Kanske 6-7 år. En händelse, vilken som helst. Vem var du då? Vad tänkte du? Kände du? Se personen framför dig. Vad som hände. Känn det den lilla versionen av dig kände och tänkte. Se att det var du. Den person som sitter här nu, var också där då. Du har varit du hela ditt liv.

Din kropp har förändrats. Allting förändras. Tänkt på hur din kropp har utvecklats och förändrats genom ditt liv.

Dina roller. De roller du har tagit och haft under ditt liv, har varit olika. Ändå har de alla varit $d u$. Du fanns med där, $i$ alla roller, $i$ alla dina former.

Tänk nu på dina känslor. Lägg märke till hur dina känslor hela tiden förändras. Ibland är du glad, ibland är du ledsen. Arg. Lugn. Pigg. Intresserad. Uttråkad. Avslappnad. Det enda du kan räkna med gällande dina känslor är att de förändras, växlar. De kan komma i vågor, men de passerar med tiden. Men även om dina känslor förändras, är du ändå där. Du är en konstant. Genom allt, så är du du. Så lägg nu bara märke till dina känslor för ett ögonblick. Och lägg märke till att du märker dem just nu.

Sen har vi dina tankar. Genom ditt huvud flyter många tankar. Märk hur de kommer till dig. Lägg märke till hur de ständigt förändras. Utvecklas. Byter. Kommer. Och försvinner. Se hur många tankar du har haft, bara idag sedan du kom in hit i rummet. Lägg bara märke till den processen. Och lägg märke till att du lägger märke till det. En del av dig står bakom, och iakttar allt det här. Lägg märke till hur du nu iakttar dina tankar en stund.

Stig tillbaka och se. Alla dina roller, tankar, känslor. Minnen. Upplevelser. Alla dessa saker är innehållet $i$ ditt liv, delar av ditt liv. De är innehåll. Medan DU är arenan. Du är sammanhanget. Kontexten. Allt du har varit med om, allt du har känt och tänkt. Igenom allt har du varit du. Du är större än dina tankar, dina känslor, dina erfarenheter, dina roller, dina sidor. Du är hela sammanhanget. Du är du. Se nu en stund på dig själv. Den som har varit med hela tiden. $\mathrm{Nu}$ vill jag att du åter igen ser dig själv här i rummet. Hur du sitter här på stolen. Tillsammans med oss andra. Du sitter här och andas. Djupa andetag. Andas in energin som finns här $i$ rummet, och när du känner dig redo, kom tillbaka hit och öppna ögonen.

\section{Kick your buts}

(Defusion, acceptance)

Klienterna får ta fram sin lista med "jag vill... men.." meningar, eller komma ihåg dem. Om de inte har gjort detta så dela ut papper och be dem skriva ned något som de vill göra, men som något har hindrat dem från. Ex. Jag vill komma i tid till jobbet, men jag är så morgontrött. Låt dem skriva ned några sådana exempel själva. Vi förklarar här hur känslorna och språket kan få en stor inverkan på ens liv. Man vill göra något, men så är det en massa orsaker eller känslor eller jobbiga saker som dyker upp i vägen (ev. skriv exempel på tavlan när ni förklarar). Ordet men har i sig inte så stor mening, men placerat i ett sammanhang betyder det att det som står efter på något sätt motsäger det som stått innan. Att de två fraserna inte kan existera samtidigt. Så om man säger "jag vill gå och hälsa på min vän, men jag är trött" innebär det att man inte kan vara både trött och gå och hälsa på en vän. Är det så verkligen?.... Ordet "men" får er alltså att utesluta en aktivitet från ert liv. Titta/tänk på de meningar ni själv skapade tidigare, med det ni vill i livet, och vad som hindrar er... Vad skulle hända om vi sparkade ut ordet men, och istället satte dit och? Till exempel "jag älskar min man, och jag blir arg på honom ibland"... Det här enkla utbytet av ett ord skulle innebära ett nytt sätt att se på livet?! Om man säger "jag vill gå och hälsa på min vän, och jag är trött” är det en ärligare återgivning av verkligenheten. Båda 
alternativen existerar, det ena utesluter inte det andra. Ni kan fortfarande välja fritt om ni vill gå och hälsa på er vän ändå! Jag vill att ni nu ändrar om era meningar och säger dem med "och" istället. Det ger er acceptans av känslan, utan att ni för den skull måste avsäga er det ni vill $i$ livet.

Vad tror ni om detta?

\section{Schackbrädet}

(Defusion, acceptance of self)

Jag vill att vi ska göra en övning som liknar den övning vi gjorde förra gången. Vi ska testa detta igen med hur man kan angripa striden man ofta har med sina tankar och känslor.

Väljer ut en person som ska spela huvudrollen. Jag vill att ni andra ska spela schakpjäser som befinner sig på ett bräde som här representeras av rummet. Några ska spela vita, de är de tankar som är för det som xxx vill, de andra ska spela svarta och vara emot det som xxx vill. Ni pjäser kommer här att diskutera med varandra, ni för ett litet krig mot varandra, de svart pjäserna mot de vita, två och två. Ni får gärna komma på egna argument medan ni driver den här stiden. Har $d u, x x x$, något område som du har funderat och tvekat över, och inte kunnat tagit tag $i$ ? .... . Jag vill att ni andra kommer på argument för och emot detta. ... Ni får ställa er här nu mot varandra båda sidorna och argumentera. Driver på diskussionen så att båda sidor pratar vilt emot varandra alla samtidigt. ... Terapeuten visar sen personen att han/hon ska gå in och lägga sig i diskussionerna, vandra runt mellan de olika paren som argumenterar mot varandra på schackbrädet.... Sen tar man en paus.... Hur gick detta? .... Vi prövar en annan variant. Ni får återigen börja argumentera mot varandra och så ska vi göra på ett annat sätt. .... Jag vill nu att du går upp och ställer dig här på stolen, att du ser utöver ditt schackbräde, som är dig, ser en överblick, utan att lägga dig $i$ varje argument och tanke... Lyssna och se över, men låt inget argument dra in dig. Betrakta det hela och samtidigt skapa en bild av dina mål och se din livskompass som du har skissat upp tidigare.... Hur kändes nu detta perspektiv? ....

Du är inte kampen, du är inte alla diskussionerna och argumenten, tankarna och känslorna, de är delar av dig, du är mer än detta. Du kan stå över ditt schackbräde. De kommer alltid att vara med dig, vilken riktning du än väljer. Du behöver inte gå in i kampen, du behöver inte skärma av dig från den och stänga av den. Du kan acceptera den och välja.

\section{Kontroll}

(Control, defusion)

Efter övningen kan det vara lämpligt att diskutera begreppet kontroll. Prata lite om hur man kan välja i sitt liv. Hur man kan kontrollera sin yttre miljö, sin bostad, sina kläder, sina saker, men inte sina inre känslor och tankar. De innehåller viktig information och är en del av en själv, men om man fastnar för mycket i dem och låter dem styra en så tappar man sin livsriktning, sin vitalitet. Ev. dra en metafor, ex. tänkt inte på en rosa elefant. Återkoppla till schackbrädet. Man kan inte välja och kontrollera vilka tankar och känslor som springer runt där, men man kan välja om man ska göra som de säger eller inte.

\section{Rehab-mötet}

(Exposure, acceptance)

$\mathrm{Nu}$ ska vi spela en övning som säkert många av er har varit med om. Vi ska spela en jobbig situation. Vi kallar den rehab-mötet. Vi ska spela hur du ska få fram det du vill i det här mötet tillsammans med den obehagliga känslan i det här mötet. Jag vill att ni ska föreställa er det 
värsta som kan hända i den här situationen, det hemskaste de närvarande kan uttrycka och tycka. Vi ska undersöka vad man riskerar när man uttrycker det man vill säga och önskar även om man är rädd att bli bemött med avvisanden. Och om det är värt detta hur än man blir bemött.

Terapeuten ber en person spela huvudrollen, en person som har varit inom vården och haft besvär länge, eller frågar om någon varit med om rehabmöte, tyckte det var jobbigt och kan tänka sig spela detta här igen. Har du haft ett rehabmöte? Vilka brukar var med där? (ex. överläkare, arbetsgivare, representant från försäkringskassan, sjukgymnast, någon från AMI för utbildning).... Vi ska här spela din mardröm, det ska vara så svårt som möjligt. Terapeuten instruerare varje person i sin roll genom att fråga huvudpersonen vad som är mest obehagligt med den här personen. Vad de värsta är som de kan uttrycka, vad personen är rädd att de ska tycka. Vad de som spelar tycker som personen ogillar. Okej, då vet alla vem de spelar, då går vi in på mötet. Överläkaren hälsar alla välkomna, och uttrycker sina tankar och slutsatser....

Försäkringskassan och läkaren hamnar i diskussion om sjuk eller frisk. En efter en lägger sig $i$ och uttrycker det de tycker. Ingen vill ha dig dit. De lägger fram halvdåliga förslag. Talar falskt, ointresserade, avvisande. Talar överhuvudet på personen. Diskuterar honom/henne öppet. Hur känns det här xxx? Vad tänker du? .... Okej, då vill jag att du ska göra på ett annat sätt. Vad skulle du vilja få ut av och tjäna på det här mötet, trots att det är jobbigt? .... Jag vill att du ska skaffa en plan, du har med dig en skriftlig plan med vad du vill själv. Att du tar en mer aktiv och ledande roll, och ger alla din plan. Uttrycker dina högre värderingar, mål, önskningar i din behandlingsplan. Att du går fram och hälsar på alla först, välkomnar dem, "vad kul att du kunde komma hit”, ser dem i ögonen och välkomnar deras hjälp. Du inleder och tar befälet. Visar vad du vill. Förhåller sig till dem som att de är ditt team, de är där för att hjälpa dig. Bortser från dina rädslor och tankar om vad de tänker och tycker om dig och din situation. När de uttrycker sina åsikter så bemöter du dem ärligt och förklarar hur du känner dig och hur deras åtgärder har fungerat för dig samtidigt som du uttrycker att du förstår deras synpunkter. Uttryck vad du vill, bemöt deras åsikter, välkomna dem, och säg ändå vad du önskar själv.... Spelar igen. Hur kändes nu detta när du uttryckte dina högre värdering, mål och önskningar?... Vad tänker ni andra om den här situationen, och hur en liten attityd förändring från xxx's sida förändrade hela situationen, även om han/hon var rädd och osäker? Vad är det man riskerar när man uttrycker det man vill? (att de inte vill ha en tillbaka, att de avvisar en och säger emot) Är det värt risken att uttrycka detta ändå, och få bemöta detta? Ingenting är riskfritt, man kan aldrig garantera att man får vad man vill. Men man kan försöka uttrycka det $i$ alla fall.

\section{Hemläxa}

(Acceptance)

Mindfulness övning med ???CD-skiva??? delas ut och pressenteras hur de ska gå tillväga. De ska sitta bekvämt och lyssna på skivan en gång per dag. (Alternativt att vi går igenom en enkel övning som de själv kan göra hemma efter en skriftlig instruktion på papper)

Sedan instrueras de i den andra delen av hemläxan, en responspreventions övning. De ska utföra något de vill/behöver göra som brukar innebära smärta eller obehag. De ska sedan sätta ett mål att genomföra detta under en lagom stund, och verkligen gå in i det, lyssna på kroppen, och med medveten närvaro utföra saken och känna alla känslor som kommer till dem. Undersöka känslan och de tankar som kommer upp. Det är bra om de för lite anteckningar efter övningen.

\section{Public-commitment}

(Commitment) 


\section{Appendix A}

Som förra gången ska vi avsluta med en commitment övning. Detta gång görs det mer högtydligt. De får gå fram framför alla och uttrycka som tidigare vad de önskar, vad de fruktar, vad som hindrar dem, vad de ska göra. Vi börjar med att möbler om lite, och skapar en scen med stolar framför, som för en publik.

Jag vill nu att alla ska ställa sig upp en och en som förra gången. Gå fram hit fram och säga högt till alla vad ni önskar i livet, vad ni är rädd för gällande detta, vad som hindrar er, och vad ert första steg på vägen mot detta ska bli. Jag och co-terapeuten börjar. Ni som sitter på stolarna ser på och finns till för personen. Ni skapar ett utrymme för dem att finnas och uttrycka sig. Du som står här uppe. Ser ut över publiken. De finns här för att lyssna på dig. En mänsklighet, gemenskap. Känn den värmen och närheten vi kan förmedla för varandra idag. Alla har vi liknande önskningar och smärtor i livet, alla är vi människor.

Ev. kan man följa en person i taget upp på scenen och ställa frågorna till dem, vad de önskar, fruktar osv. Det är bra om de kan utforma sitt commitment i termer av "jag vill", "jag ska", inte "försöka, borde, kanske". Var ett stöd för personen. Det är okej alla känslor som kan komma. Ni har alla slitigt här länge, mycket smärta och sorg. Nu ska ni här ta tag $i$ ert liv och föra det dit ni vill.

Efter detta avslutas sessionen. 
Appendix A

\title{
SESSION 4 - Individuell inriktning och avslut
}

Individuell session med en terapeut, ca. 1,5 timmar.

\author{
Värderingar \\ Mindfulness \\ Regler \\ Avslut- hur går jag vidare? \\ Exempel på andra ämnen, övningar och metaforer
}

Mål: Prata om deras värderingar. Mindfulness. Självbild. Ev. analys av regler. Hur ska de gå vidare själva?

Mer fri, individuellt anpassad, tar upp personliga tankar och funderingar hos individen. Följer samma områden som tidigare, sammanfattar lite. Leder in på hur de ska gå vidare med sitt liv och sin situation, vilka tankar som väckts.

Terapeuten får här fritt utforma sessionen tillsammans med klienten.

Centrala områden som bör täckas är som tidigare värderingar, willingness, commitment, acceptance. Detta kan ske genom samtal, genom övningar och metaforer.

Förslag på övningar finns även under session 1. Nedan följer ytterligare några. De finns mer detaljerat beskrivna i ACT-boken.

\section{Värderingar}

Gå tillbaka till de värderingar som klienten angav första gången och i sin värderingskompass. Se att de är djupa och meningsfulla för individen. Prata om hinder och willingeness. Referera till övningar vi gjort som ex. kick your buts.

\section{Mindfulness}

Kan vara lämpligt att åter göra en mindfulness övning i någon form. Gärna efter något tema som observerande självet, känna känslor, uppleva minnesbilder. Se hur det har gått för klienten med hemläxan, att lyssna på CD skivan. Tala om meningen med medveten närvaro. Att känna sina känslor och se sina tankar. Acceptera att de existerar och är med en. Men att man själv står över dessa känslor och tankar. Man själv är större, och fri att välja sina val oavsett tankar, känslor och minnen.

\section{Regler}

Prata om vilka regler som klienten sätter upp för sig själv, för andra och för livet i allmänhet. Är reglerna sanna? Verkliga? Måste det vara så? Måste de följas? Analyser deras regler tillsammans och visa på funktionen av att ha dessa regler i deras liv.

Avslut- hur går jag vidare? 


\section{Appendix A}

Commitment kan här vara relevant. Hur tänker klienten gå vidare? Vad har denna tänk på och lärt sig under de här träffarna? Har terapin gett klienten någon ny insikt? Prata om hur klienten kan gå vidare på olika sätt, i ett mer närvarande och vitalitet.

\section{Exempel på andra ämnen, övningar och metaforer}

Responsprevention. Vad leder dem in i negativa cirklar. Vad kan de göra annorlunda. Känna den känsla som de försöker undkomma eller ignorera. Hur de kan utöka sin beteende reportoar? Ev. koppla till den hemuppgift de haft.

Funktionell analys. Finns det någon särskild situation som är problematisk för dem. Rita upp en funktionell analys. Vad leder till vad?

Metaforer: Joe the bum, path up the mountains, the swamp, take your keys with you, m.fl. 


\section{Livskompassen}

Tips för olika områden i sin egen livskompass:

Se det här som en process som får ta tid. Det är viktigt att du skriver/skrivit ned vad du tycker är viktigt eller värdesätter om det inte är något som står i din väg. Frågan är inte vad som är realistiskt för dig att uppnå eller vad andra eller du tycker att du förtjänar. Det viktiga är att göra tydligt för dig själv vad du vill arbeta mot i den bästa av situationer.

Intima relationer/nära relationer/parrelationer: Beskriv hur du vill vara i en nära relation. Skriv vilken typ av förhållande du vill ha. Fokusera på din roll i relationen. Hur du vill vara i relationen, och vad du vill få ut av den.

Familjerelationer: Beskriv hur du vill vara som bror/syster, far/mor, son /dotter. Beskriv vilka kvaliteter vill du ha i relationer till andra i din familj. Beskriv hur du skulle behandla andra $i$ dessa relationer om du vore ditt perfekta jag.

Vänner/socialt liv: Skriv vad det innebär för dig att vara en god vän. Om du hade möjlighet att vara en perfekt vän hur skulle du då vara? Beskriv ett idealiskt vänskapsförhållande.

Arbete: Beskriv den typ av arbete du vill arbeta med, det kan vara specifikt eller generellt, kom ihåg att det är en idealvärld vi föreställer oss. Beskriv varför detta perfekta arbete tilltalar dig. Diskutera också vilken typ av medarbetare du vill vara. Hur vill du att dina arbetsrelationer ska se ut?

Utbildning och personlig utveckling: Hur vill du utvecklas genom livet om du fick välja helt fritt? Vad är du nyfiken på? Varför vill du utbilda dig överhuvudtaget? Om du skulle vilja genomföra en informell eller formell utbildning så skriv om vilken typ av utbildning som tilltalar dig. Beskriv din intention i området snarare än mål.

Fritidsaktiviteter: Beskriv det liv du vill leva på din fritid. Vad vill du fylla din fritid med? Kom ihåg att du inte beskriver hur det är i ditt liv just nu utan hur det ser ut i din värld om du väljer helt fritt och förutsättningslöst. Ta med t.ex. intressen, hobbies, sporter och fritidsaktiviteter. Vad vill du få ut av din fritid?

Andlighet och harmoni: Det här behöver inte innebära religion. Vad som menas med andlighet är helt enkelt det du tycker att det betyder. Det kan handla om att uppleva naturen eller gå i kyrkan. Det kan handla om tid för sig själv, tid för reflektion, sina egna tankar, ro och harmoni. Skriv hur du vill att det ska vara precis som i de andra områdena.

Samhällsengagemang: Att vara en del i ett större sammanhang är en viktig del i många människors liv. Vissa tycker till exempel att det är viktigt att arbeta frivilligt för hemlösa eller äldre människor. Andra vill delta i politik eller grupper som engagerar sig i vissa sakfrågor. Hur vill du vara som medborgare i det samhälle vi lever i? Beskriv dig själv som den medborgare som du vill vara och vad som är betydelsefullt i samhället.

Egenvård: Hälsa och fysiskt välmående. Här kan du skriva om dina värderingar som är kopplade till att utveckla och bibehålla din fysiska hälsa. Skriv om ämnen som handlar om hälsan, som sömn, rökning, motion, mat med mera. Hur vill du behandla din kropp? Hur vill du ta hand om din kropp?

Föräldraskap: Hur vill du vara som förälder? Vad är viktigt för en vuxen mot barn? Det spelar ingen roll om du har barn själv utan vad är viktigt tycker du i att vara förälder. Beskriv hur du vill vara som förälder? Beskriv hur du vill vara mot barn. 
Appendix B

\begin{tabular}{|c|c|}
\hline Intima relationer & \\
\hline Familjerelationer & \\
\hline Vänner/socialt liv & \\
\hline Arbete & \\
\hline Utbildning/utveckling & \\
\hline Fritidsaktiviteter & \\
\hline Andlighet/harmoni & \\
\hline
\end{tabular}




\section{Bulls-Eye dagbok}

\section{-för att finna steg i sin värderade riktning och att leva i linje med det man vill att livet skall handla om.}

\section{Tips för de olika områdena i sin egen livs-kompass:}

Se det här som en process som får ta tid. Det är viktigt att du skriver/skrivit ned vad du tycker är viktigt eller värdesätter om det inte är något som står i din väg. Frågan är inte vad som är realistiskt för dig att uppnå eller vad andra eller du tycker att du förtjänar. Det viktiga är att göra tydligt för dig själv vad $d u$ vill arbeta mot i den bästa av situationer.

1. Intima relationer/nära relationer/parrelationer: Beskriv hur du vill vara i en nära relation. Skriv vilken typ av förhållande du vill ha. Fokusera på din roll i relationen. Hur du vill vara i relationen, och vad du vill få ut av den.

2. Familjerelationer: Beskriv hur du vill vara som bror/syster, far/mor, son /dotter. Beskriv vilka kvaliteter vill du ha i relationer till andra i din familj. Beskriv hur du skulle behandla andra i dessa relationer om du vore ditt perfekta jag.

3. Vänner /socialt liv: Skriv vad det innebär för dig att vara en god vän. Om du hade möjlighet att vara en perfekt vän hur skulle du då vara? Beskriv ett idealiskt vänskapsförhållande.

4. Arbete: Beskriv den typ av arbete du vill arbeta med, det kan vara specifikt eller generellt, kom ihåg att det är en idealvärld vi föreställer oss. Beskriv varför detta perfekta arbete tilltalar dig. Diskutera också vilken typ av medarbetare du vill vara. Hur vill du att dina arbetsrelationer ska se ut?

5. Utbildning och personlig utveckling: Hur vill du utvecklas genom livet om du fick välja helt fritt? Vad är du nyfiken på? Varför vill du utbilda dig överhuvudtaget? Om du skulle vilja genomföra en informell eller formell utbildning så skriv om vilken typ av utbildning som tilltalar dig. Beskriv din intention i området snarare än mål.

6. Fritidsaktiviteter: Beskriv det liv du vill leva på din fritid. Vad vill du fylla din fritid med? Kom ihåg att du inte beskriver hur det är i ditt liv just nu utan hur det ser ut i din värld om du väljer helt fritt och förutsättningslöst. Ta med t.ex. intressen, hobbies, sporter och fritidsaktiviteter. Vad vill du få ut av din fritid?

7. Andlighet och harmoni: Det här behöver inte innebära religion. Vad som menas med andlighet är helt enkelt det du tycker att det betyder. Det kan handla om att uppleva naturen eller gå i kyrkan. Det kan handla om tid för sig själv, tid för reflektion, sina egna tankar, ro och harmoni. Skriv hur du vill att det ska vara precis som i de andra områdena.

8. Samhällsengagemang: Att vara en del i ett större sammanhang är en viktig del i många människors liv. Vissa tycker till exempel att det är viktigt att arbeta frivilligt för hemlösa eller äldre människor. Andra vill delta i politik eller grupper som engagerar sig i vissa sakfrågor. Hur vill du vara som medborgare i det samhälle vi lever i? Beskriv dig själv som den medborgare som du vill vara och vad som är betydelsefullt i samhället. 
9. Egenvård: Hälsa och fysiskt välmående. Här kan du skriva om dina värderingar som är kopplade till att utveckla och bibehålla din fysiska hälsa. Skriv om ämnen som handlar om hälsan, som sömn, rökning, motion, mat med mera. Hur vill du behandla din kropp? Hur vill du ta hand om din kropp?

10. Föräldraskap: Hur vill du vara som förälder? Vad är viktigt för en vuxen mot barn? Det spelar ingen roll om du har barn själv utan vad är viktigt tycker du i att vara förälder. Beskriv hur du vill vara som förälder? Beskriv hur du vill vara mot barn.

\section{Mål vs riktning}

Riktning kan liknas med en vision eller en intention som inte är möjlig att uppnå. T.ex. om du vill ta dig västerut så är det möjligt att göra det hela livet. västerut finns alltid och det är alltid möjligt att ta dig längre västerut. På samma sätt är det med din hälsa och de andra områdena i livskompassen. Om du vill känna dig stark, ha god kondition och äta hälsosamt så är det något som du behöver vara aktiv igenom hela livet. Mål på den vägen är konkreta, uppnåbara och mätbara. T.ex. att träna på gym, gå på promenad, laga en hälsosam god måltid är aktiviteter med en början och ett slut. Att vara aktiv för att utveckla och bibehålla en god hälsa är ett livslångt åtagande.

I värderingskompassen arbetade du med intention av vad du vill att livet skall handla om. I Bulls-Eye dagboken kommer du att arbeta med mål och steg som överensstämmer med dina värderingar. Samtidigt som du arbetar med att finna mål och steg i enlighet med dina värderingar, utvärderar du i dagboken om det du gör i vardagen överensstämmer med det du vill och värderar. 
Appendix B

\section{Övning: Bulls-Eye}

Använd din värderingskompass som stöd för att finna områden där du vill utvecklas. Börja med att välja ett område och skriv det på raderna nedan. Skriv också hur du vill vara i det området du valt. Alltså skriv din intention/vision i det området:

Värderingsriktning:

Använd nu raderna nedan och skriv ner ett steg du kan tänka dig att ta i din värderade riktning. Välj ett steg att ta och utvärdera sedan om det är i din värderade riktning genom att använda din piltavla. Det är oftast bättre att ta ett litet steg än inget alls. Tiderna blir inte bättre, du kan inte bestämma över framtid eller dåtid, utan bara här och nu. Vad vill du ska hända inom det område du valt att värdera? Vilket steg kan/vill du ta för att komma närmare ditt ideal-liv just nu? Skriv ner det steg du väljer på raderna nedan och genomför det under dagen.

\section{Steg att ta:}

I den sista delen placerar du ett $\mathbf{X}$ på piltavlan som bäst visar hur väl det steg du tog under dagen överensstämmer med vad du vill att livet skall handla om, d.v.s din värdering. Mitt i Bulls-Eye innebär perfekt överensstämmelse mellan det du gör och hur du vill att det skall vara. Du har sedan 4 nivåer att välja mellan. "Mycket långt ifrån" innebär sämst överensstämmelse mellan hur du vill att det skall vara och hur det är. Placera nu ditt $\mathbf{X}$ som bäst visar överrensstämmelsen mellan det du gjorde och hur du vill att det skall vara.

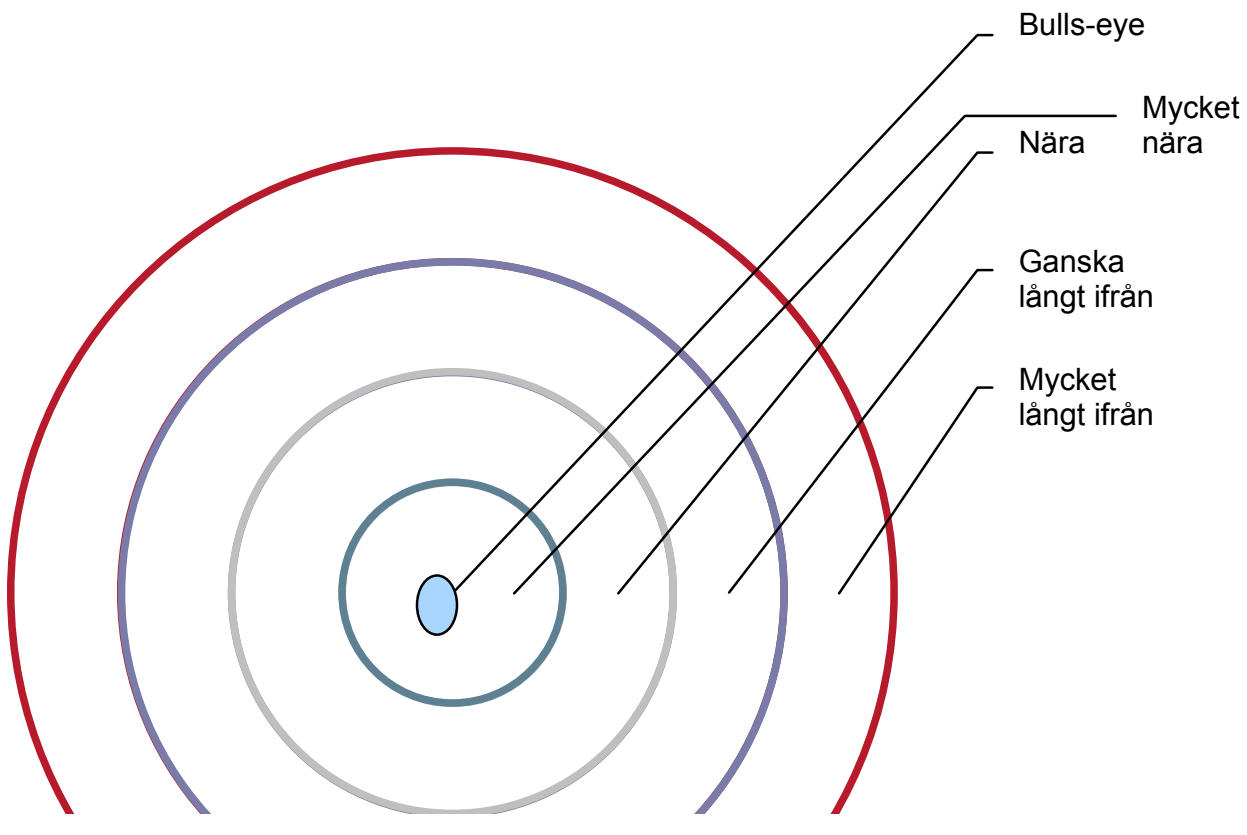




\section{Vitala aktiviteter vs icke vitala aktiviteter}

Hur skall man mäta sina steg? Att vara i Bulls-Eye innebär att leva i vitalitet. Göra saker i enlighet med sina egna värderingar innebär att inte tvinga sig och göra för någon annans skull. Inte heller för att "vara rätt" eller för att läkaren sagt så eller för att din make/maka vill. Det skall vara för dig och för ditt liv, för att hedra ditt liv och dina värderingar. Att leva i Bulls-Eye innebär att vara där du får ut det du vill av livet, där du är i linje med vad du vill att livet skall stå för. Man kan beskriva det som att bli helt uppslukad av något och att det känns bra i hela kroppen. En hjälp kan vara att gå tillbaks till egna erfarenheter och se på tillfällen då man verkligen känt sig helt uppe i en aktivitet. Ni kommer säkert på många egna exempel då ni gjort saker som varit vitala och saker ni gjort som verkligen inte varit vitala. Detta ska handla om dina egna val och din egen vitalitet. Det är bara du som kan värdera i ditt eget liv och det är ditt val om du gör det. Det som vi är ute efter här är att titta på kvaliteten i de aktiviteter som ni väljer att göra. Ingen kan alltså säga att det där var bra för dig eller inte. Det är din erfarenhet efter att ha tagit steget som avgör om det var en "mitt i prick-pil" eller en "långt ifrån-pil" som du kastade iväg. Det är handlar alltså inte om att göra rätt eller fel utan snarare om att göra något och utvärdera om du fann vitalitet i det du gjorde.

\section{Bulls-Eye i vardagen}

Nedan följer 7 stycken piltavlor. När du kliver upp på morgonen väljer du ett område från värderingskompassen. Fundera sedan vad du under dagen skall göra för att ta ett steg i din valda värderingsriktning. När du sedan kommer hem på kvällen sätter du ett kryss på din piltavla på det ställe som bäst representerar hur den aktivitet du valde var i din värderade riktning. Det vill säga om utfallet av det du valde att göra blev som du tänkte. Ha så kul under veckan och bra jobbat! 
Appendix B

\section{Dag 1}

Värderad riktning:

Steg som jag skall ta under dagen:

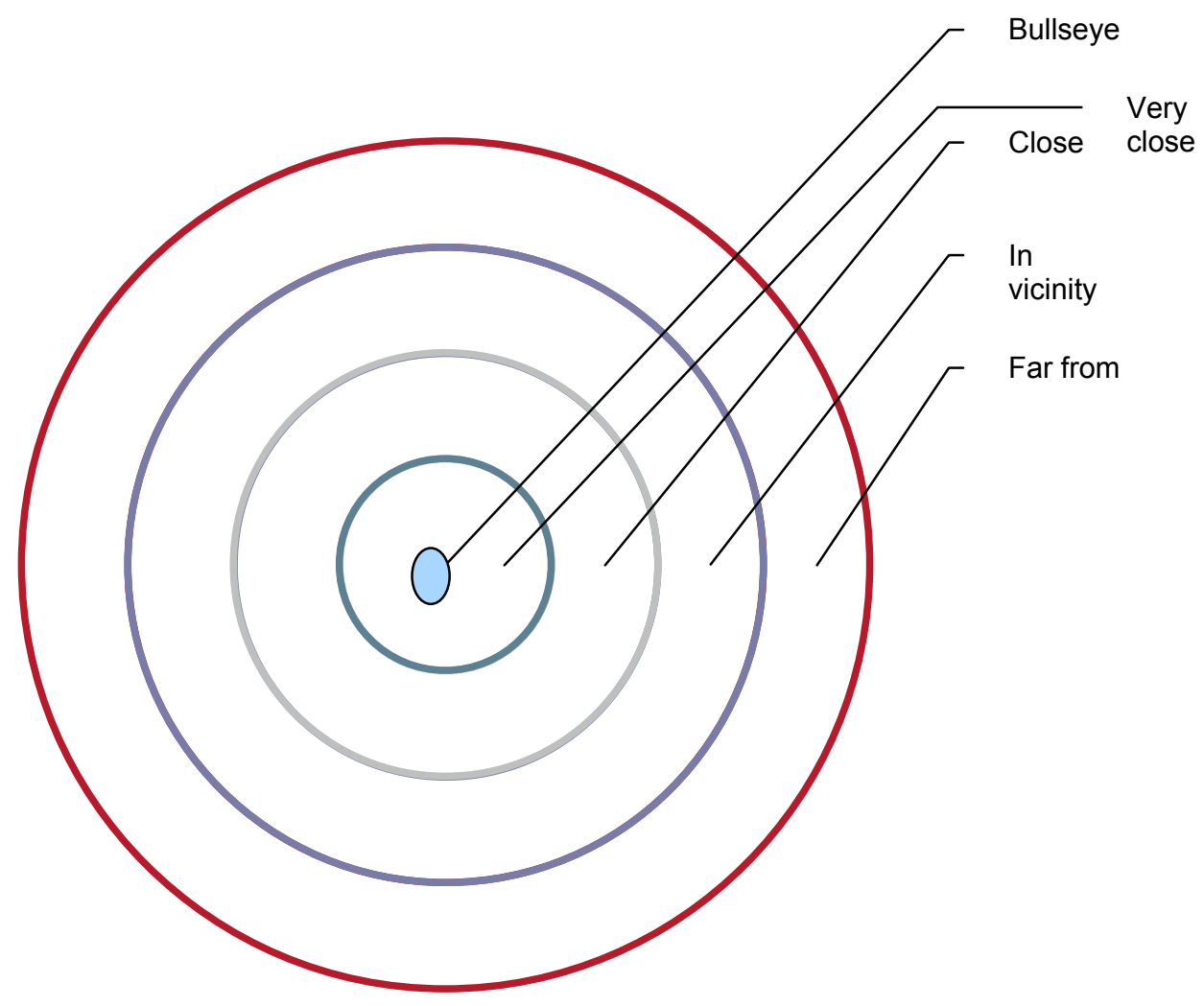

Placera ditt $\mathbf{X}$ där det bäst representerar om det du valde att göra under dagen överrensstämmer med hur du vill att det skall vara. 
Appendix B

\section{Gravstenen:}

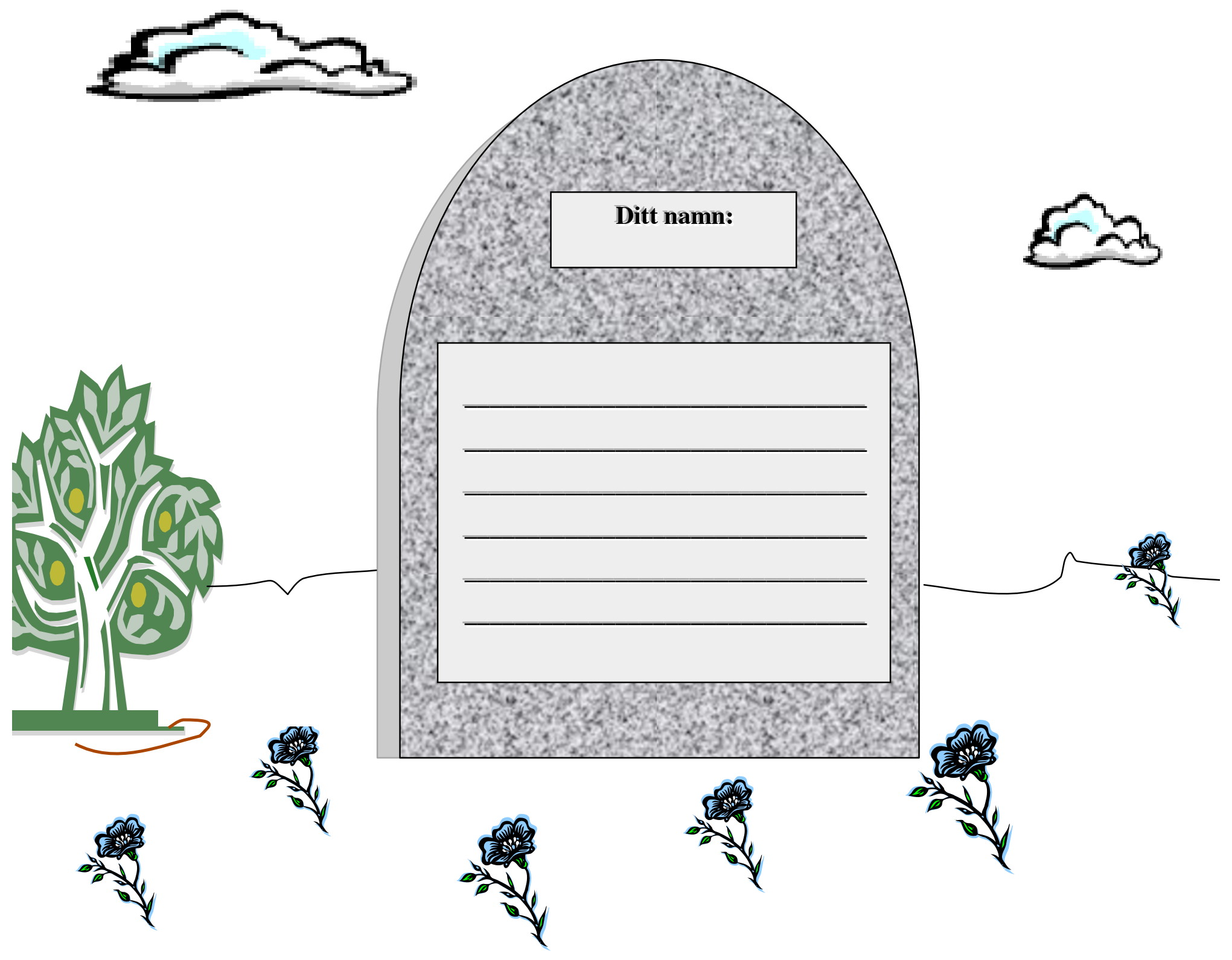


Appendix B

Hemuppgift 3, arbetsblad.

Skriv ner när du har övat medveten närvaro, vilken aktivitet du gjort, och om några funderingar dykt upp under eller efter övningen.

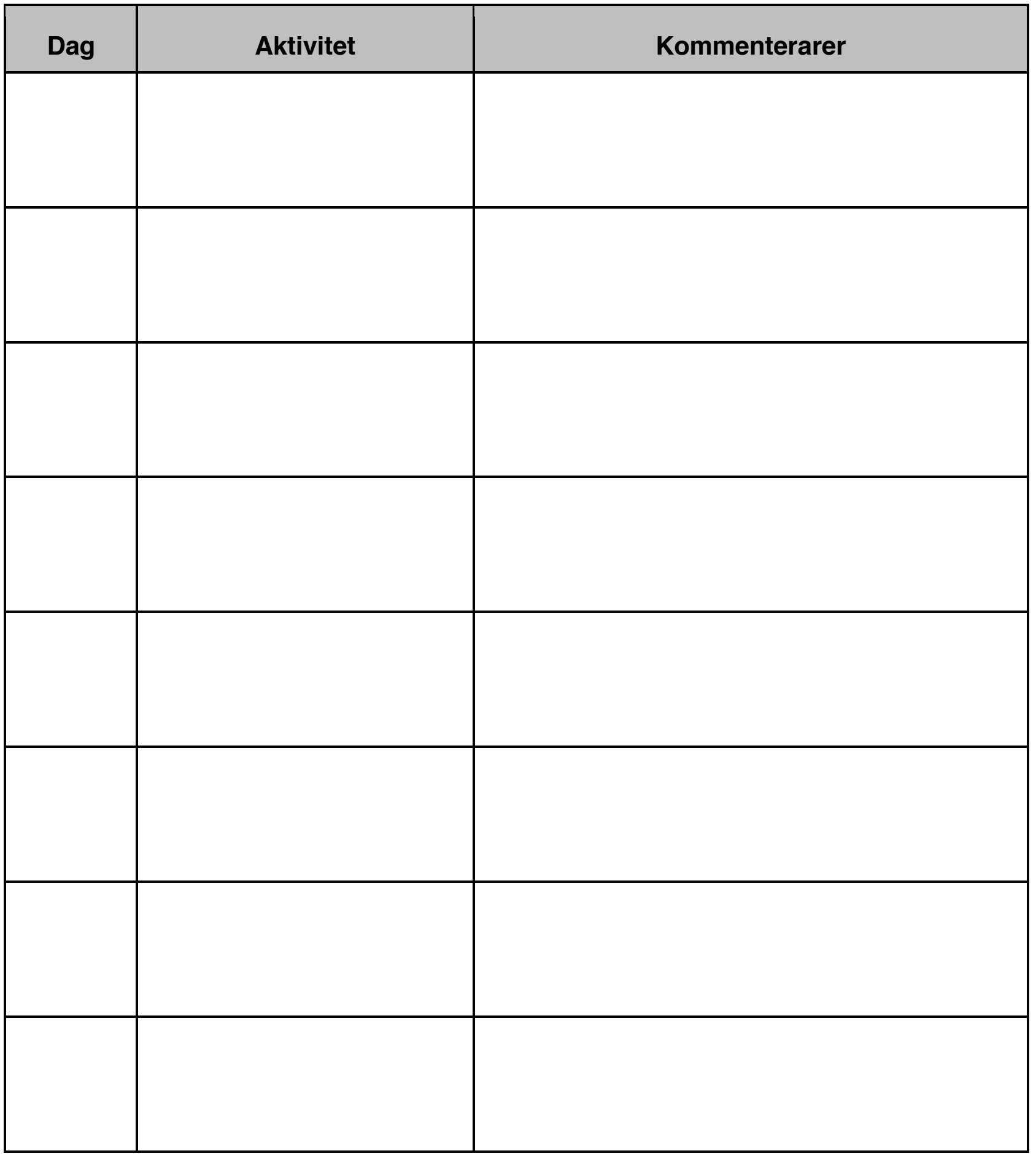


Appendix C

\section{CPAQ}

Nedan finner du ett antal påståenden. Skatta hur sant varje påstående är för dig genom att ringa in en siffra. Använd skalan nedan för att göra dina val.

Exempel: Om du anser att ett påstående är "alltid sant" ringar du in siffran sex.

\begin{tabular}{|c|c|c|c|c|c|c|}
\hline $\begin{array}{c}0 \\
\text { Aldrig } \\
\text { sant }\end{array}$ & $\begin{array}{c}1 \\
\text { Mycket } \\
\text { sällan } \\
\text { sant }\end{array}$ & $\begin{array}{c}2 \\
\text { Sällan } \\
\text { sant }\end{array}$ & $\begin{array}{c}3 \\
\text { Sant } \\
\text { ibland }\end{array}$ & $\begin{array}{c}4 \\
\text { Ofta } \\
\text { sant }\end{array}$ & $\begin{array}{c}5 \\
\text { Nästan } \\
\text { alltid } \\
\text { sant }\end{array}$ & $\begin{array}{c}6 \\
\text { Alltid } \\
\text { sant }\end{array}$ \\
\hline
\end{tabular}

\begin{tabular}{|l|l|l|l|l|l|l|l|}
\hline $\begin{array}{l}\text { 1. Jag fortsätter att leva som vanligt oavsett hur mycket } \\
\text { smärta jag har. }\end{array}$ & 0 & 1 & 2 & 3 & 4 & 5 & 6 \\
\hline $\begin{array}{l}\text { 2. Mitt liv fungerar bra även fast jag har kronisk smärta. } \\
\text { 3. Det är OK att uppleva smärta. }\end{array}$ & 0 & 1 & 2 & 3 & 4 & 5 & 6 \\
\hline $\begin{array}{l}\text { 4. Jag skulle gärna avstå ifrån viktiga saker i mitt liv för att } \\
\text { kunna kontrollera min smärta bättre. }\end{array}$ & 0 & 1 & 2 & 3 & 4 & 5 & 6 \\
\hline $\begin{array}{l}\text { 5. Det är inte nödvändigt för mig att kontrollera min smärta för } \\
\text { att kunna hantera mitt liv bra. }\end{array}$ & 0 & 1 & 2 & 3 & 4 & 5 & 6 \\
\hline $\begin{array}{l}\text { 6. Även om saker har förändrats lever jag ett normalt liv trots } \\
\text { min kroniska smärta. }\end{array}$ & 0 & 1 & 2 & 3 & 4 & 5 & 6 \\
\hline $\begin{array}{l}\text { 7. Jag måste fokusera på att bli av med min smärta. } \\
\text { 10. Att kontrollera smärtan är mindre viktigt än andra mål i } \\
\text { mitt liv. }\end{array}$ & 0 & 1 & 2 & 3 & 4 & 5 & 6 \\
\hline $\begin{array}{l}\text { 8. Det finns många aktiviteter som jag gör när jag känner } \\
\text { smärta. }\end{array}$ & 0 & 1 & 2 & 3 & 4 & 5 & 6 \\
\hline $\begin{array}{l}\text { 9. Jag lever ett fullvärdigt liv trots att jag har kronisk smärta. } \\
\text { a }\end{array}$ & 0 & 1 & 2 & 3 & 4 & 5 & 6 \\
\hline
\end{tabular}


Appendix C

\begin{tabular}{ccccccc}
0 & 1 & 2 & 3 & 4 & 5 & 6 \\
$\begin{array}{c}\text { Aldrig } \\
\text { sant }\end{array}$ & $\begin{array}{c}\text { Mycket } \\
\text { sällan } \\
\text { sant }\end{array}$ & $\begin{array}{c}\text { Sällan } \\
\text { sant }\end{array}$ & $\begin{array}{c}\text { Sant } \\
\text { ibland }\end{array}$ & $\begin{array}{c}\text { Ofta } \\
\text { sant }\end{array}$ & $\begin{array}{c}\text { Nästan } \\
\text { alltid } \\
\text { sant }\end{array}$ & $\begin{array}{c}\text { Alltid } \\
\text { sant }\end{array}$ \\
\hline
\end{tabular}

\begin{tabular}{|c|c|c|c|c|c|c|c|}
\hline $\begin{array}{l}\text { 11. Mina tankar och känslor om smärtan måste } \\
\text { förändras innan jag kan gå vidare med mitt liv. }\end{array}$ & 0 & 1 & 2 & 3 & 4 & 5 & 6 \\
\hline 12. Trots smärtan lever jag mitt liv som planerat. & 0 & 1 & 2 & 3 & 4 & 5 & 6 \\
\hline $\begin{array}{l}\text { 13. Att hålla min smärta under kontroll har högsta } \\
\text { prioritet när jag gör något. }\end{array}$ & 0 & 1 & 2 & 3 & 4 & 5 & 6 \\
\hline $\begin{array}{l}\text { 14. Innan jag kan göra upp några bestämda planer } \\
\text { måste jag få viss kontroll över min smärta. }\end{array}$ & 0 & 1 & 2 & 3 & 4 & 5 & 6 \\
\hline $\begin{array}{l}\text { 15. När min smärta ökar kan jag fortfarande sköta det } \\
\text { jag har ansvar för. }\end{array}$ & 0 & 1 & 2 & 3 & 4 & 5 & 6 \\
\hline $\begin{array}{l}\text { 16. Om jag kan kontrollera mina negativa tankar kring } \\
\text { smärtan får jag bättre kontroll över mitt liv. }\end{array}$ & 0 & 1 & 2 & 3 & 4 & 5 & 6 \\
\hline $\begin{array}{l}\text { 17. Jag undviker att sätta mig i situationer där smärtan } \\
\text { skulle kunna öka. }\end{array}$ & 0 & 1 & 2 & 3 & 4 & 5 & 6 \\
\hline $\begin{array}{l}\text { 18. Min oro och rädsla över vad smärtan kan göra mig } \\
\text { är sann. }\end{array}$ & 0 & 1 & 2 & 3 & 4 & 5 & 6 \\
\hline $\begin{array}{l}\text { 19. Det är en lättnad att inse att jag inte behöver } \\
\text { förändra min smärta för att gå vidare med mitt liv. }\end{array}$ & 0 & 1 & 2 & 3 & 4 & 5 & 6 \\
\hline $\begin{array}{l}\text { 20. Jag måste kämpa för att göra saker när jag har } \\
\text { smärta. }\end{array}$ & 0 & 1 & 2 & 3 & 4 & 5 & 6 \\
\hline
\end{tabular}


Appendix C

\section{The Satisfaction with Life Scale (SWLS)}

Nedan ser Du fem påståenden. Använd den 7-gradiga skalan nedan för att ange hur väl Du tycker att varje påstående stämmer för Dig. Fyll i Ditt svar på linjen före varje påstående.

Den 7-gradiga skalan är:

$1=$ Stämmer mycket dåligt

$2=$ Stämmer dåligt

$3=$ Stämmer ganska dåligt

4= Stämmer varken bra eller dåligt

$5=$ Stämmer ganska bra

$6=$ Stämmer bra

$7=$ Stämmer mycket bra

I de flesta avseenden ligger mitt liv nära mitt ideala liv.

Mina livsvillkor är utmärkta.

Jag är tillfreds med mitt liv.

Hitintills har jag fått de viktiga saker jag vill ha i livet.

Om jag fick leva om mitt liv skulle jag i stort sett inte ändra på någonting alls. 


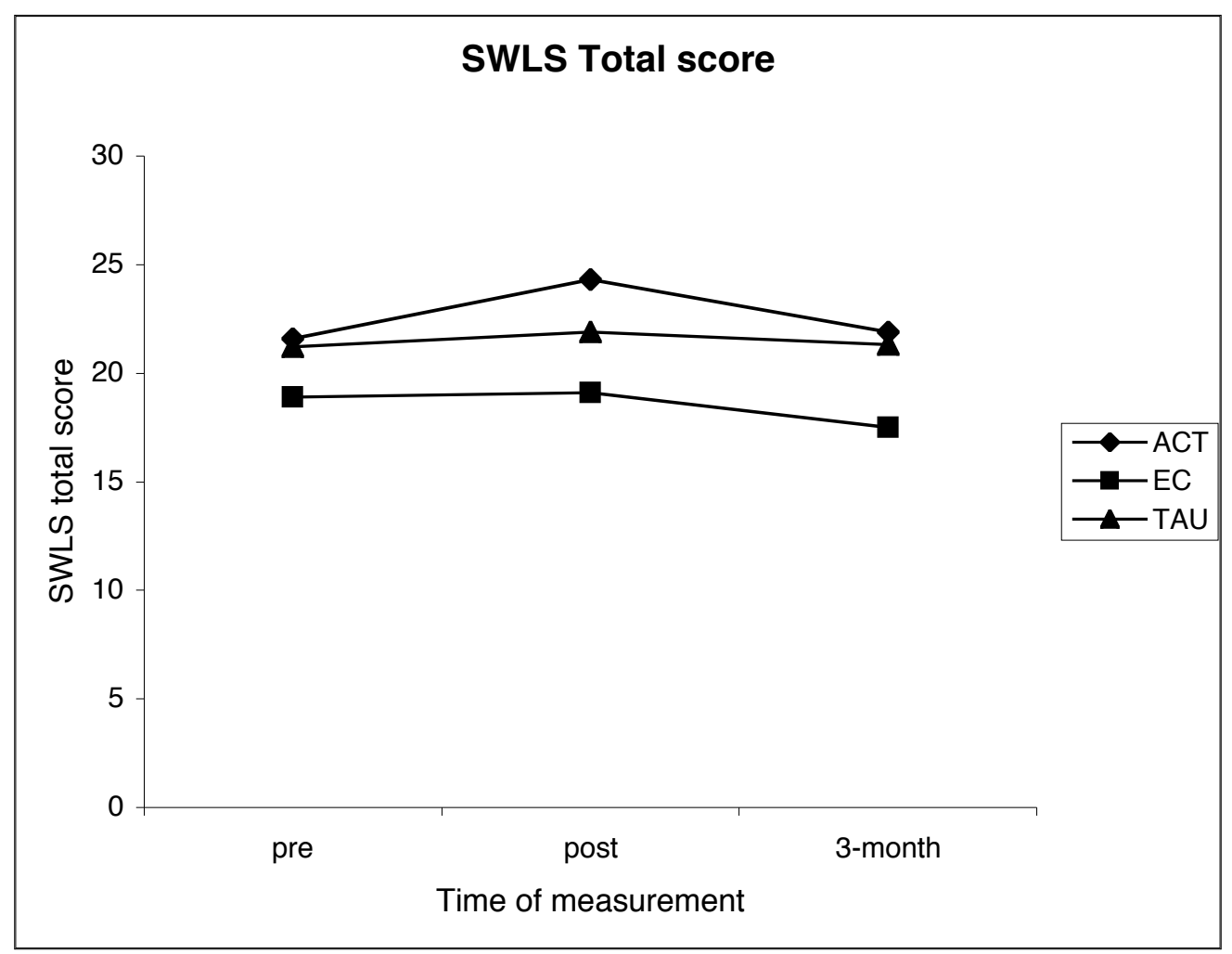

Figure D1. SWLS Total scores for all groups at pre-treatment, post-treatment and 3-month follow-up.

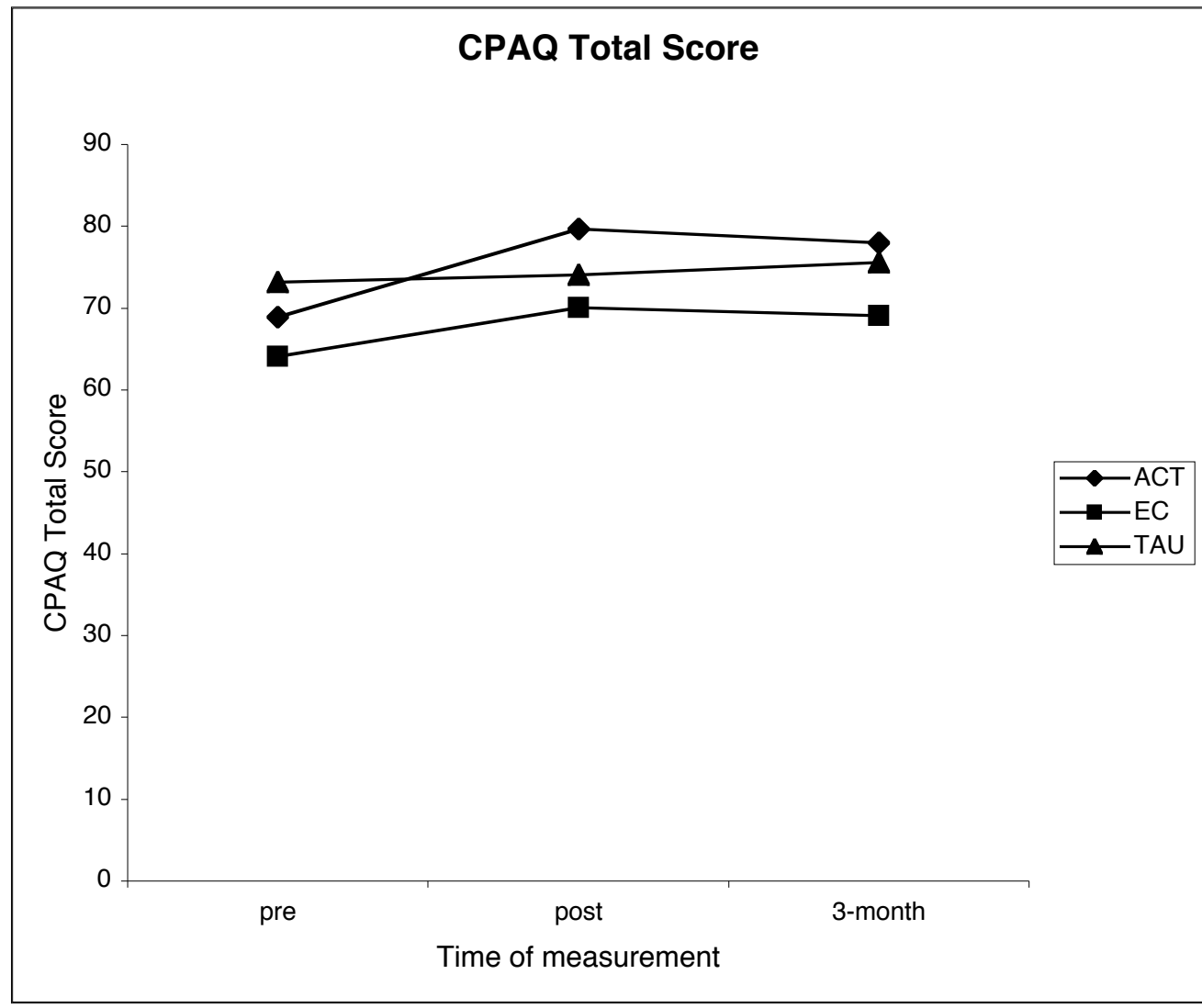

Figure D2. CPAQ Total scores for all groups at pre-treatment, post-treatment and 3-month follow-up. 


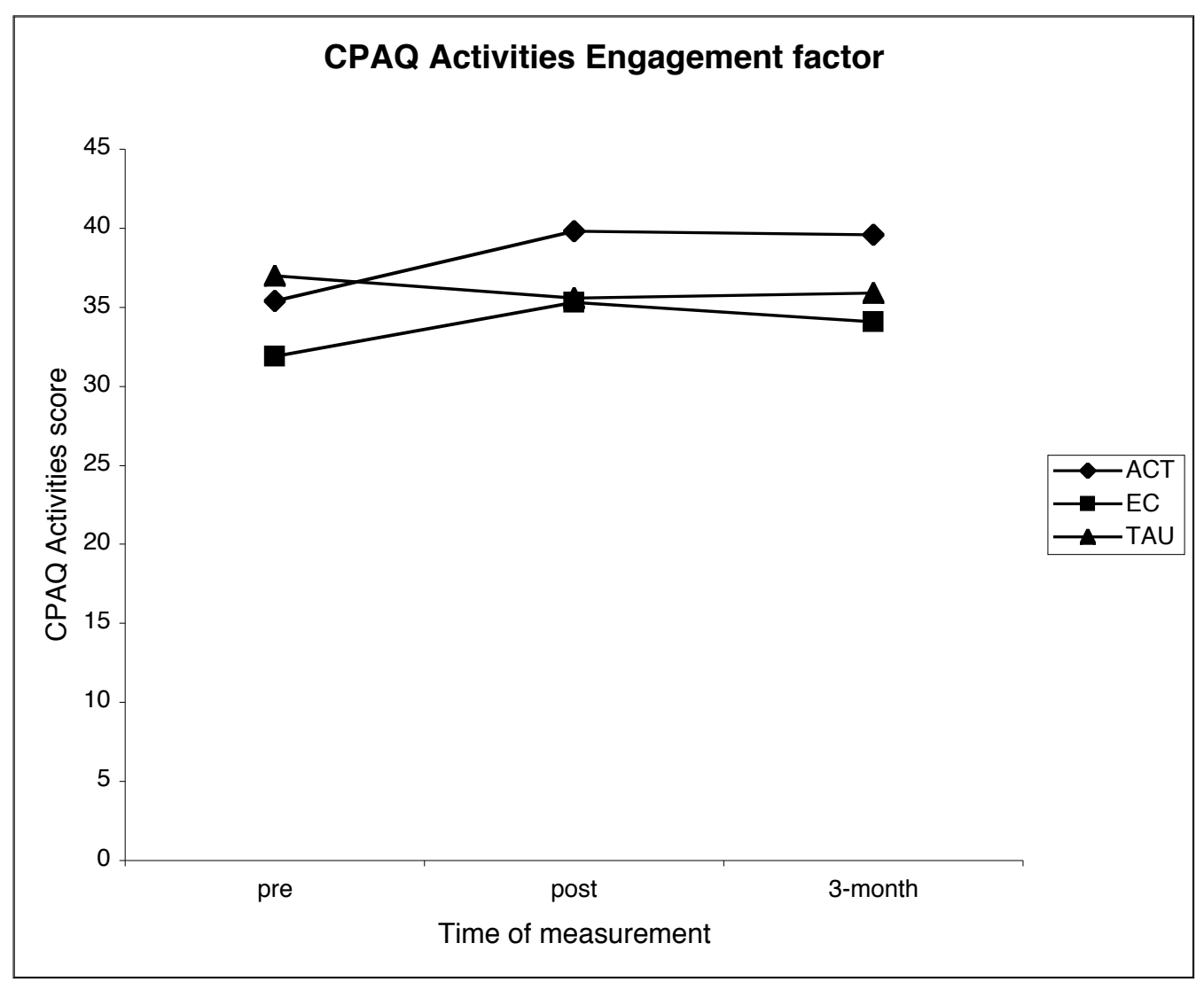

Figure D3. CPAQ subfactor Activities Engagement scores for all groups at pre-treatment, posttreatment and 3-month follow-up.

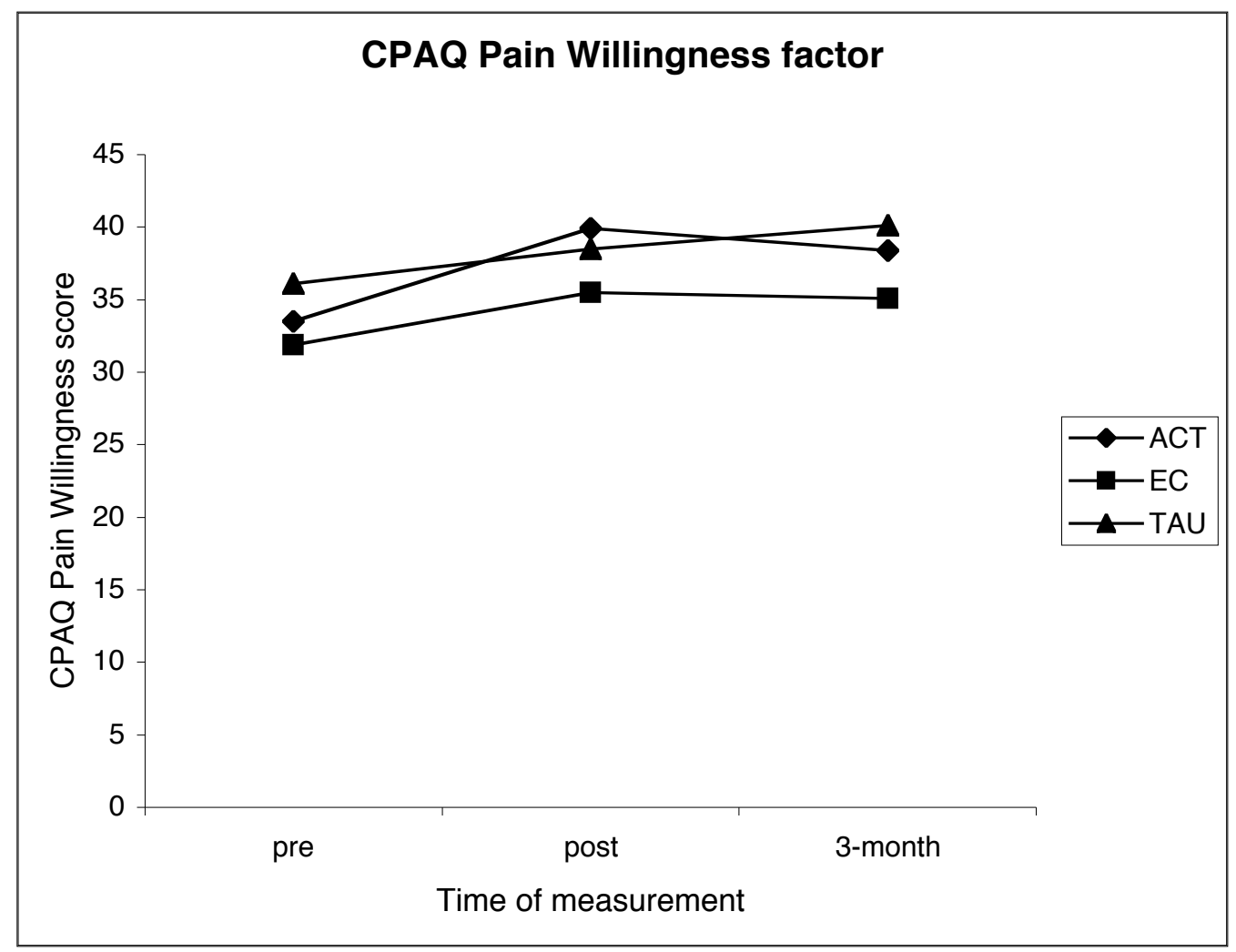

Figure D4. CPAQ subfactor Pain Willingness scores for all groups at pre-treatment, post-treatment 


\section{Appendix D}

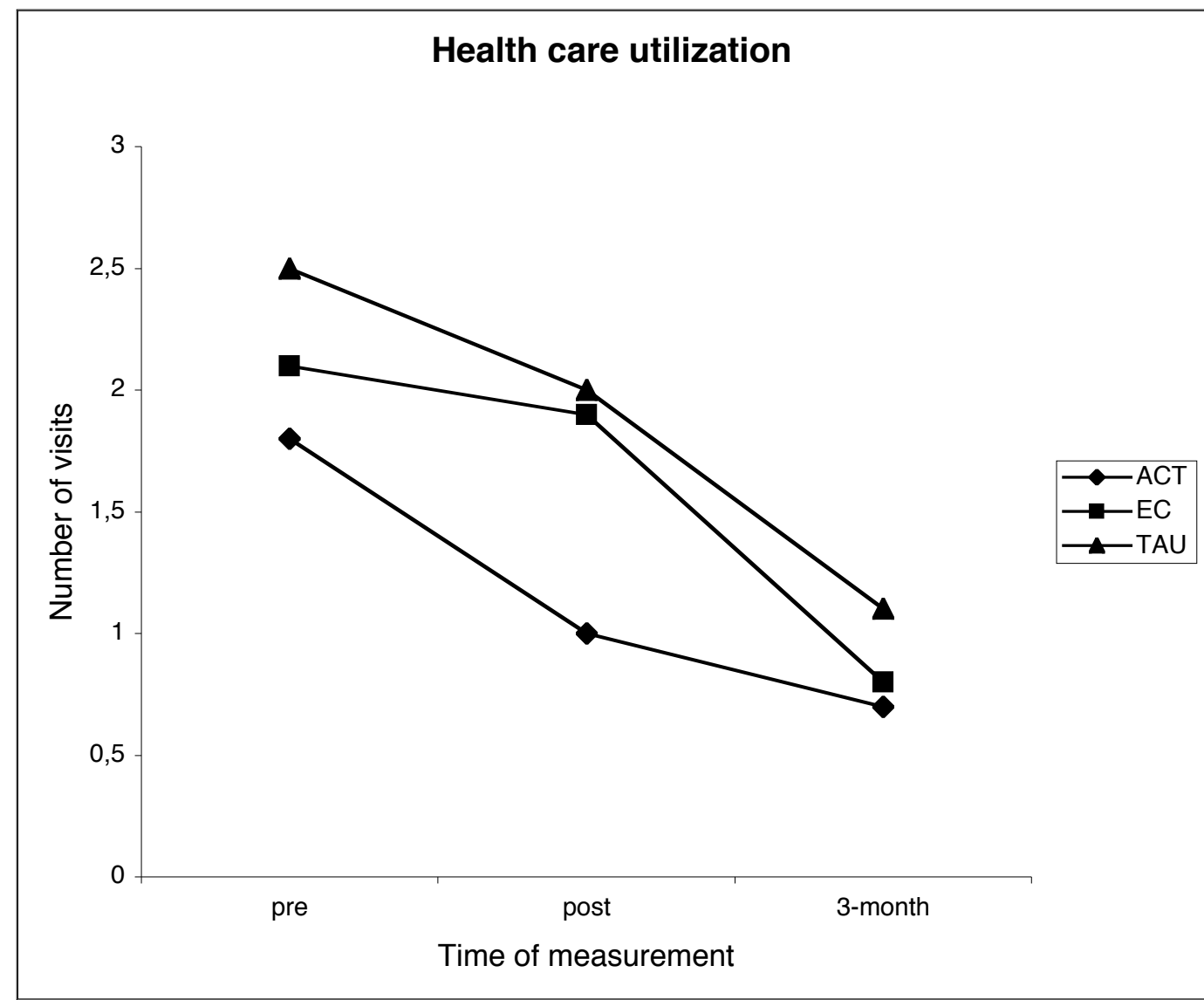

Figure D5. Number of visits to health care because of pain. Data from all groups at pre-treatment, post-treatment and 3-month follow-up. 